\title{
Thermokarst in Siberian ice-rich permafrost: Comparison to asymmetric scalloped depressions on Mars
}

\author{
M. Ulrich, ${ }^{1}$ A. Morgenstern, ${ }^{1}$ F. Günther, ${ }^{1}$ D. Reiss, ${ }^{2}$ K. E. Bauch, ${ }^{2}$ E. Hauber, ${ }^{3}$ \\ S. Rössler, ${ }^{4}$ and L. Schirrmeister ${ }^{1}$ \\ Received 27 April 2010; revised 29 May 2010; accepted 18 June 2010; published 20 October 2010.
}

[1] On Earth, the thawing of permafrost deposits with high-ground ice content results in massive surface subsidence and the formation of characteristic large thermokarst depressions. Slope asymmetries within thermokarst depressions suggest lateral growth, which occurs due to thermoerosion and gravimetric mass wasting along these slopes. It has been proposed that rimless, asymmetrically shaped depressions (called scalloped depressions) on Mars were formed by insolation-driven ground ice sublimation. We investigated a large thermokarst depression in ice complex deposits in the Siberian Arctic as a terrestrial analogue for scalloped depressions in Martian volatile-rich mantle deposits. Our results from field studies, insolation modeling, and geomorphometric analyses suggest lateral thermokarst development in a northern direction. This conclusion is obvious due to steeper slope angles of the south facing slopes. Insolation and surface temperatures are crucial factors directly influencing thermokarst slope stability and steepness. Comparative analyses of Martian scalloped depressions in Utopia Planitia were conducted using high-resolution (High-Resolution Imaging Science Experiment, Context Camera) and thermal infrared (Thermal Emission Imaging System) satellite data. By direct analogy, we propose that the lateral scalloped depression development on Mars was primarily forced on the steep pole-facing slopes in the equator-ward direction. Insolation modeling confirms that this must have happened in the last $10 \mathrm{Ma}$ during an orbital configuration of higher obliquity than today. Development would have been maximized if the orbit was both highly oblique and highly eccentric, and/or the Martian summer coincided with perihelion. Relatively short events of increasing sublimation or even thawing of ground ice led to fast slumping processes on the steep pole-facing slopes.

Citation: Ulrich, M., A. Morgenstern, F. Günther, D. Reiss, K. E. Bauch, E. Hauber, S. Rössler, and L. Schirrmeister (2010), Thermokarst in Siberian ice-rich permafrost: Comparison to asymmetric scalloped depressions on Mars, J. Geophys. Res., 115, E10009, doi:10.1029/2010JE003640.

\section{Introduction and Background}

[2] The visual similarity of terrestrial thermokarst depressions and Martian scalloped depressions implies comparable periglacial origins linked to extensive degradation of ground ice. Assumed thermokarst development cannot be transferred one-to-one to scalloped depressions, but the study of analogous terrestrial thermokarst properties within a well-known environment contributes to an improved understanding of periglacial landscape evolution on Mars considering pre-

\footnotetext{
${ }^{1}$ Alfred Wegener Institute for Polar and Marine Research, Research Unit Potsdam, Potsdam, Germany.

${ }^{2}$ Institut für Planetologie, Westfälische Wilhelms-Universität Münster, Münster, Germany.

${ }^{3}$ Institute for Planetary Research, German Aerospace Center (DLR), Berlin, Germany.

${ }^{4}$ Limnological Institute, Technical University of Munich, Iffeldorf, Germany.

Copyright 2010 by the American Geophysical Union. 0148-0227/10/2010JE003640
}

vailing Martian hydrological and climatic conditions. Following Morgenstern et al. [2007], the Siberian ice complex landscape is suggested as a terrestrial analogue for Martian degraded volatile-rich mantle deposits [Kreslavsky and Head, 2000; Mustard et al., 2001]. Thermokarst-affected landscapes are widely distributed in Northeast Siberian icerich permafrost deposits called ice complexes. Thermokarst as a process of permafrost degradation is caused by disturbances of the thermal equilibrium in the upper permafrost zone and results in surface subsidence and characteristic landforms in Arctic lowlands [Czudek and Demek, 1970; Soloviev, 1973; French, 2007]. Such disturbances can have long-term regional causes (e.g., climate changes) but may also result from temporally and spatially limited nonclimatic reasons (e.g., destruction of the vegetation cover, local erosion). Large thermokarst depressions of several square kilometers (i.e., alasses), often filled with lakes and separated by flattened hills, are the most striking landscape elements (referred to as Yedoma) in parts of the Siberian Arctic lowlands [Grosse et al., 2006, 2007; Schirrmeister 
et al., 2008]. Particularly, the high-ground ice content (up to $90 \%$ by volume) of ice complex deposits formed during the late Pleistocene by various periglacial processes [Schirrmeister et al., 2008] is a crucial factor for the development of large thermokarst depressions because surface subsidence is related to ice volume loss [e.g., Romanovskii et al., 2000]. Generally, the development took place in several stages [Czudek and Demek, 1970; Soloviev, 1973; Romanovskii et al., 2000] and was probably initiated by the warmer and moister climate conditions during the Late Glacial to Early Holocene transition (10-12 ka) [Grosse et al., 2007]. Increasing insolation in the Northern Hemisphere due to Earth's orbital parameter variations [Berger and Loutre, 1991] was probably an important factor for the major landscape changes during this time [Grosse et al., 2007]. Initially, rapid enlargement of water bodies corresponds to massive thawing of ice-rich deposits under deepening thermokarst lakes. After lake drainage, surface subsidence results in large thermokarst depressions with steep slopes [Czudek and Demek, 1970; Soloviev, 1973; Everdingen, 2005]. Further deepening might be prevented if ground ice depleted material forms an insulating layer at a later stage. Lateral growth of thermokarst basins occurs due to thermoerosion along the slopes (i.e., thermoabrasion) and gravimetric mass wasting. Preliminary studies indicate a specific asymmetric morphometry of these permafrost degradation features in Siberian ice-rich deposits suggesting spatially directed thermokarst processes [Morgenstern et al., 2008a] but the potential driving processes are still unclear.

[3] Comparably shaped depressions and permafrost degradation features on Mars were first interpreted as thermokarst in origin by Sharp [1973]. These "scallops" or scalloped depressions are rimless depressions (a few hundred meters to several kilometers in diameter), which can coalesce to form large areas of scalloped terrain that exhibit a northsouth asymmetrical shape, opposed on both hemispheres with the steeper slopes pointing poleward [Morgenstern et al., 2007; Lefort et al., 2009, 2010; Zanetti et al., 2010]. They are present in Mars' midlatitude regions in close proximity to a volatile-rich (i.e., water ice rich) mantle layer tens of meters thick, which was deposited during variations in Mars' orbital parameters (i.e., obliquity and eccentricity) [Kreslavsky and Head, 2000, 2002; Mustard et al., 2001; Head et al., 2003]. Various authors have studied the surface morphology of scalloped depressions on Mars and suggested formation processes controlled by solar insolation, which resulted in an asymmetric sublimation of ground ice with respect to the aspect (i.e., north-south) [Morgenstern et al., 2007; Lefort et al., 2009, 2010; Zanetti et al., 2010] or an origin by ponding water comparable to terrestrial drained-thermokarst lake depressions [Costard and Kargel, 1995; Soare et al., 2007, 2008].

[4] In this work, techniques for comparatively analyzing scalloped and thermokarst depression properties are combined with terrestrial field studies to emphasize similarities in and differences between these morphological analogues. In section 2, overviews of the investigated terrestrial and Martian areas are given separately to highlight the similarity of these sites, including the geomorphological and geological characteristics. Section 3 reviews data acquisition during field work and the methods used to determine geomorphometry and thermal properties, first of the terres- trial thermokarst depression and then of the Martian scalloped depressions. Next we present results of geomorphometric analyses of the investigated thermokarst depression including observations made during field work and new results from insolation modeling (section 4.1). Comparable results of geomorphometric analyses and insolation modeling of Martian scalloped depressions are presented later in the same section (section 4.3). Finally, we discuss properties of terrestrial thermokarst depression asymmetry and the implications for spatially directed development of Martian scalloped depressions (section 5). The main questions of this study are as follows: (1) Which parameters control thermokarst morphology on Earth, and what can be inferred for scalloped depressions on Mars from terrestrial thermokarst topography, morphometry, and volume? (2) What is the influence of solar insolation on terrestrial thermokarst development (a factor that has been suggested as a main driving process for scallop formation on Mars)? (3) Which conclusions can be drawn from the development of scalloped depressions for the climate history and ground ice (i.e., permafrost) conditions on Mars?

\section{Regional Settings}

\subsection{Earth}

[5] Kurungnakh Island located in the southcentral Lena Delta was chosen as the terrestrial study area because it is representative of thermokarst in ice complex sediments (i.e., Yedoma) and is easily accessible for field work. The Lena Delta is situated in northeastern Siberia within the zone of continuous permafrost (Figure 1a), which at this location is several hundred meters thick and hundreds of thousands of years old. The climate is true arctic, characterized by very low mean annual air temperatures of about $-13.5^{\circ} \mathrm{C}$ and low mean annual precipitation of around $300 \mathrm{~mm}$. [ROSHYDROMET, 2009]. Kurungnahk Island is part of the third Lena Delta terrace [Grigoriev, 1993], which mainly consists of erosional fragments of a broad accumulation plain composed of late Pleistocene permafrost deposits [Schirrmeister et al., 2003] situated north of mountain ridges bordering the delta to the south (Figure 2a). The island covers an area of about $350 \mathrm{~km}^{2}$ and reaches a maximum elevation of $55 \mathrm{~m}$ a.s.l. (Figure 2b).

[6] The sediments are composed of two stratigraphically different units. The lower unit consists of sandy sediments with gravimetric ice contents of about $25 \mathrm{wt} \%$ related to the dry sediment weight. The deposits are $15-20 \mathrm{~m}$ thick and were accumulated between 100 and $50 \mathrm{ka}$ [Krbetschek et al., 2002; Wetterich et al., 2008]. The upper unit overlies the sandy deposits discordantly and is composed of ice complex deposits. The ice complex section is about $15-20 \mathrm{~m}$ thick and consists of fine-grained deposits with ice supersaturation due to the very high gravimetric ice contents (up to $150 \mathrm{wt} \%)$ [Wetterich et al., 2008]. The ice occurs in the form of huge ice wedges and segregation ice. Thus, the total amount of ice contained in the ice complex can reach $90 \%$ by volume. The syngenetically formed ice wedges are 5-7 m wide and about $20 \mathrm{~m}$ deep, indicating long-term stable landscape conditions. The Kurungnakh ice complex deposits accumulated between 50 and $17 \mathrm{ka}$ [Schirrmeister et al., 2003; Wetterich et al., 2008]. 

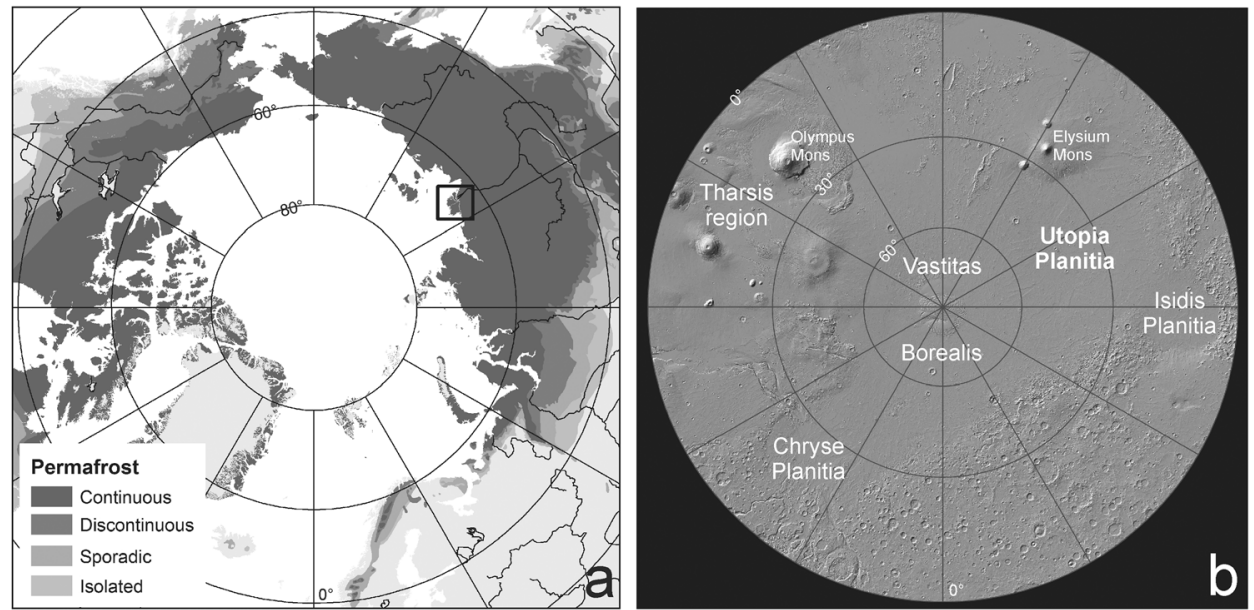

Figure 1. (a) Circum-Arctic permafrost distribution and location of the Lena Delta (rectangle) in NE Siberia (Russia) within the zone of continuous permafrost. Map based on the work of Brown et al. [1998]. (b) Location of Utopia Planitia on the Northern Hemisphere of Mars (MOLA shaded relief).

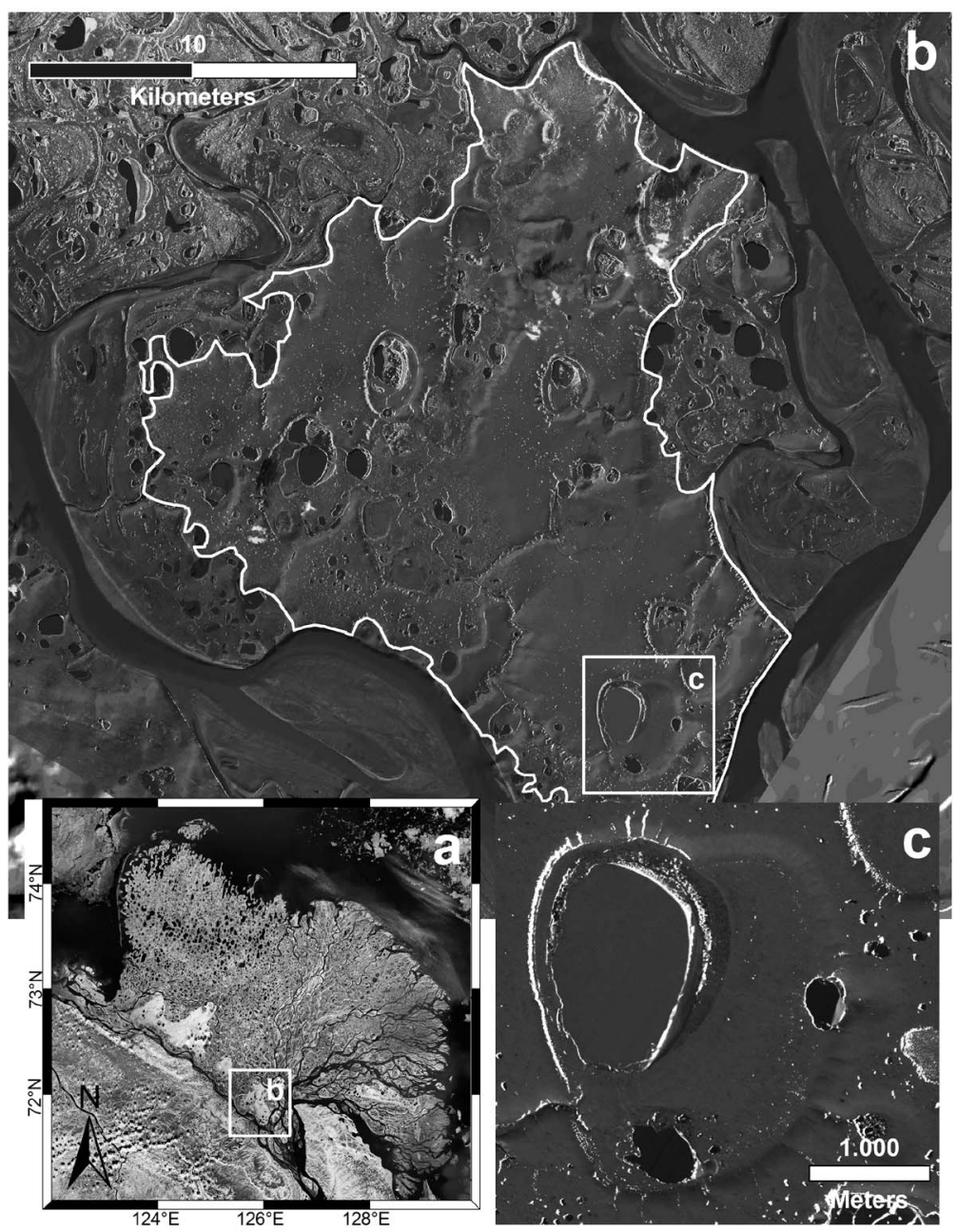

Figure 2. Regional setting of the terrestrial study site. (a) Lena Delta. Brighter colors indicate ice complex remnants in the south of the Delta (GeoCover 2000 NASA). (b) Thermokarst landscape on Kurungnakh Island in the southcentral Lena Delta; the gray line marks the distribution of ice complex deposits that have built the island (ALOS PRISM image, Date: 21 September 2006, over DEM shaded relief) (c) The Kurungnakh Island thermokarst depression on which this work is focused (ALOS PRISM subset). 


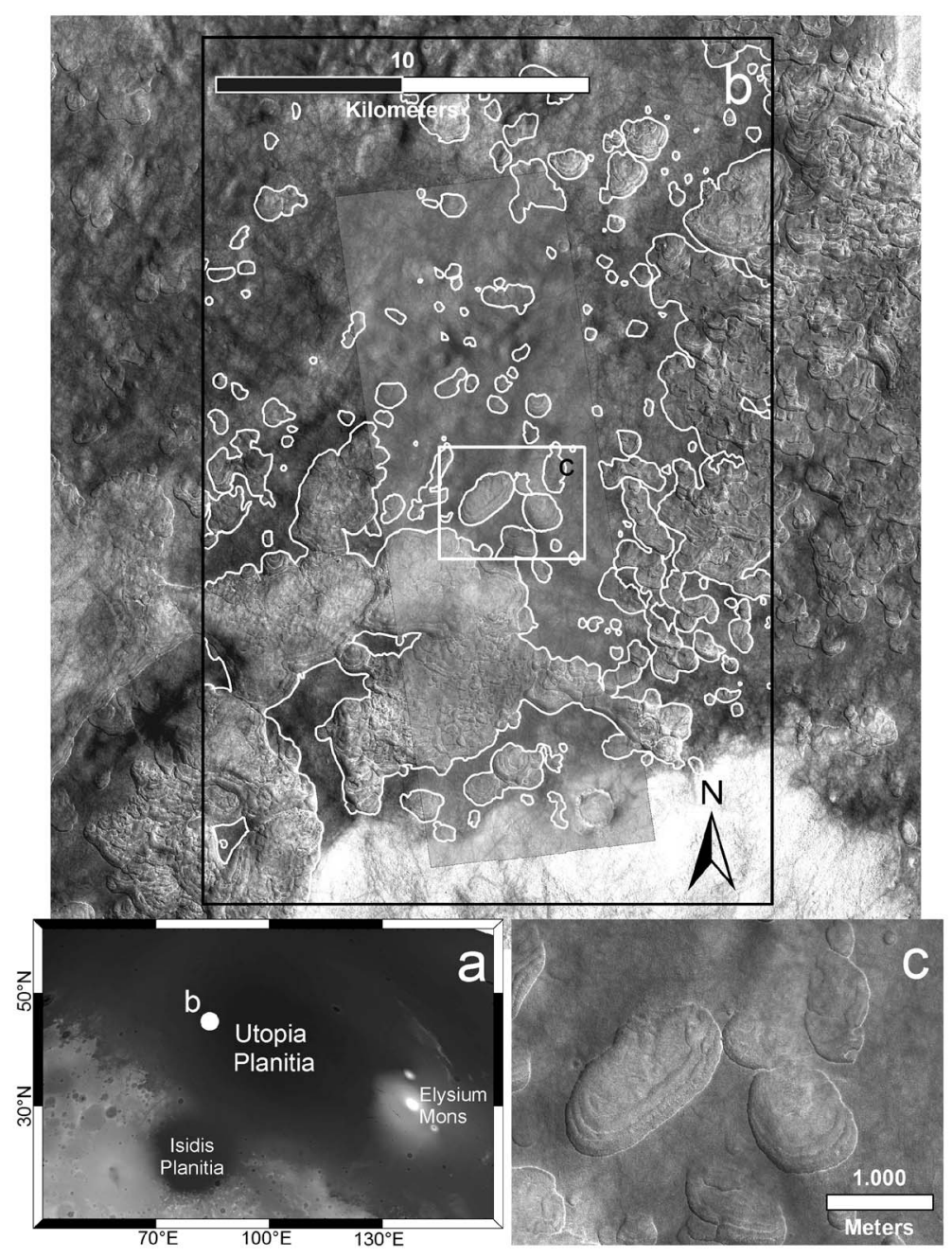

Figure 3. Regional setting of the Martian study site. (a) The studied location in western Utopia Planitia (MOLA DEM in sinusoidal projection). (b) Mapped scalloped terrain within the self-defined study site (white borders) (HiRISE image: PSP_001938_2265 on CTX image: P02_001938_2263_XI_46N267W). (c) Example of a larger single asymmetrically shaped scalloped depression (HiRISE subset).

[7] Today, the formerly consistent ice complex mantle is interrupted by thermokarst depressions filled by limnic and boggy deposits indicating ice complex degradation during the Late Glacial to Early Holocene period (ca. 12-8 ka). The surface of Kurungnakh Island is characterized by a highly dissected thermokarst landscape (Figure 2b) dominated by large thermokarst depressions (i.e., alasses) with diameters of up to $\sim 3 \mathrm{~km}$ and depths of up to $\sim 30 \mathrm{~m}$, which often coalesce to form large thermokarst valleys. The border of the island is frequently cut by thermoerosional gullies. More than $50 \%$ of the island area is occupied by thermokarst features, with about $38 \%$ covered by alasses. The depressions show steep, often asymmetrical slopes in the N-S direction and flat bottoms. About $8 \%$ of the island's area is covered by thermokarst lakes. Within the depressions, they are mostly situated at the margins. At higher elevations, the surface of the Yedoma hills is drier, better drained, and contains only small lakes and polygonal ponds. The occurrence of polygonal structures of ice wedge systems depends on the individual drainage situation. Generally, the bottoms of thermokarst depressions are dominated by low-center polygons, while high-center polygons are common on slopes or on the better-drained hill positions. The terrestrial studies described here are particularly focused on a characteristic, approximately $7.5 \mathrm{~km}^{2}$ large thermokarst depression in the southeast of Kurungnakh Island (Figure 2c).

\subsection{Mars}

[8] For comparison with our terrestrial study area, we selected an area in the northern Martian hemisphere in western Utopia Planitia (UP) (Figure 1b). This area is part of the Utopia Basin (Figure 3a) and was possibly formed by a giant impact during the pre-Noachian period (4.5-4.1 Ga) [McGill, 1989; Tanaka et al., 2005; Carr and Head, 2009]. The area is covered by the Vastitas Borealis interior unit $\left(\mathrm{ABv}_{\mathrm{i}}\right)$, which underlies the Astapus Colles unit (ABa) nearby [Tanaka et al., 2005]. The ABa unit is relatively young on the Martian time scale (Late Amazonian, 2-0.4 Ma), and is interpreted as an ice-rich mantle deposit tens of meters in thickness [Kreslavsky and Head, 2000, 2002; Mustard et al., 2001; Head et al., 2003; Carr and Head, 2009]. The $\mathrm{ABv}_{\mathrm{i}}$ unit is of Early Amazonian age $(<3.0 \mathrm{Ga})$ and 
consists of outflow channel sediments and subsequently reworked ice-rich deposits [Tanaka et al., 2005]. The region is characterized by various landforms of periglacial origin, e.g., polygonal structures, scalloped depressions, and small mounds [e.g., Soare et al., 2005, 2007, 2008; Morgenstern et al., 2007; de Pablo and Komatsu, 2009; Burr et al., 2009; Lefort et al., 2009; Levy et al., 2009]. There are strong morphological similarities between the western UP landforms and terrestrial periglacial landforms. Although the gamma ray spectrometer (GRS) on Mars Odyssey shows that this area is relatively free of water ice in the upper surface layer (about $1 \mathrm{~m}$ ) [Boynton et al., 2002; Feldman et al., 2004], the presence of possible periglacial features suggests the existence of volatile-rich (i.e., ice-rich) mantle deposits [e.g., Morgenstern et al., 2007; Lefort et al., 2009].

[9] For direct comparison with the terrestrial study site, an area of about $350 \mathrm{~km}^{2}$ in western UP was defined (Figure 3b) that is representative of scalloped and periglacial terrain on the northern plains of Mars. According to Morgenstern et al. [2007], $24 \%$ of the area between $40^{\circ} \mathrm{N}-50^{\circ} \mathrm{N}$ and $80^{\circ} \mathrm{E}-85^{\circ} \mathrm{E}$ is degraded by scalloped depressions with an increasing coverage from north to south. Our area of focus is centered at $46^{\circ} \mathrm{N}$ and $92^{\circ} \mathrm{E}$ and is located around the footprint of the High-Resolution Imaging Science Experiment (HiRISE) image PSP 001938 2265. It represents an area similar to the central section of the area described by Morgenstern et al. [2007], which is located between an almost nondegraded, smooth, and flat surface in the north, and an area in the south where the mantling material has been completely removed. The elevation of our study area ranges between $-4600 \mathrm{~m}$ in the north and $-4500 \mathrm{~m}$ in the south as indicated by topographic information from Mars Orbiter Laser Altimeter (MOLA) data [Smith et al., 2001]. The area is characterized by a generally smooth and flat surface with polygonal structures and isolated scalloped depressions beside larger coalesced and nested regions of completely removed mantle material (Figure $3 b$ ).

\section{Data and Methods}

\subsection{Terrestrial Data}

\subsubsection{Field Data}

[10] Field work was conducted during a field campaign on Kurungnakh Island (Lena Delta) in summer 2008 to investigate terrestrial thermokarst depression morphometry and surface characteristics and their controlling factors. For quantitative land surface analyses and detailed description of the thermokarst depression morphology a high-resolution digital elevation model (DEM) was necessary. Therefore, a tacheometric field survey was carried out using a ZEISS ELTA C30 tacheometer with an electro-optical distance measurement device. Altogether, 2663 points representing the thermokarst depression were measured and stored in a coordinate-point database which allows interpolation to a raster data set.

[11] Another important aim of the fieldwork was to characterize and map different relief units and geomorphological features by their distinct surface properties. Relief features (microrelief and mesorelief, slope characteristics), vegetation properties (coverage, height, vitality), hydrological conditions (soil/surface moisture, drainage situation, water bodies), and active layer depth measured by a steel rod were recorded at more than 280 sites covering the total area of the investigated thermokarst depression and the adjacent undisturbed uplands This ground truth data set was derived as a training and reference set for further remote sensing analyses.

[12] Downwelling shortwave solar radiation was measured on differently exposed thermokarst depression slopes and surfaces. Measurements were conducted between 9 and 22 August 2008 at 19 locations using a Pyranometer CS300 from Campbell Scientific, Inc. Basic cloud cover corrections were done using an algorithm developed by Laevastu [1960] and visual cloud cover observations. Several evaluations of the cloud correction algorithm at different sites [e.g., Reed, 1977; Frouin et al., 1988; Kumar et al., 1991] showed good results for the formula used, as well as for the lower sun elevations [Reed, 1977] that occur in Arctic environments. Finally, only measurements between noon and 4 P.M. were used and averaged for each location.

\subsubsection{GIS and Remote Sensing Analyses}

[13] For calculating a hydrologically correct DEM within

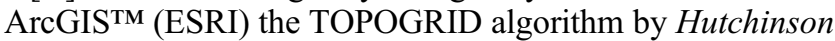
[1989] was used. A grid cell size of $3 \mathrm{~m}$ was chosen for the output DEM to reflect small-scale morphological characteristics. Vertical accuracy of the DEM was tested by comparing height values from the calculated DEM to the original point database. The root mean square error (RMSE) averaged $0.28 \mathrm{~cm}$, indicating high accuracy of the model. The DEM was used to extract morphometric parameters (slope angle, aspect, elevation, curvature) within ArcGIS ${ }^{\mathrm{TM}}$ for a quantitative terrain analyses. Each parameter was calculated on a cell-by-cell basis, fitting a plane composed of a $3 \times 3$ cell neighborhood. Furthermore, the GIS-calculated volume of the alas being investigated was used for estimating relationships between ground ice contents, surface subsidence, and thermokarst deposit sedimentation.

[14] Solar radiation influencing the thermokarst morphology is of special interest in this work. We used the solar radiation analysis tool provide by ArcGISTM to calculate insolation for the area of the thermokarst depression on Kurungnakh Island and specific point locations therein. The toolset is based on an algorithm developed by Rich et al. [1994]. Total global radiation was calculated for an arbitrary time as the sum of direct and diffuse radiation after generating upward-looking viewsheds based on each grid cell in the DEM. The solar radiation toolset performs sunmap calculations to determine direct solar radiation originating from each sky direction. Diffuse radiation was calculated using a skymap, which represents a hemispherical view of the entire sky defined by zenith and azimuth angle. The sunmap, the skymap, and the viewshed are then combined to calculate total solar radiation. The theory of the solar radiation tool is described in detail by $F u$ and Rich [1999].

[15] Model parameters were adjusted according to atmospheric and meteorological conditions in the central Lena Delta region [e.g., Boike et al., 2008]. Thus, a standard overcast diffuse model was used in which the radiation flux varies with the zenith angle. Transmittivity and diffuse proportion parameters were set to account for average sky conditions and cloud cover in the study area during summer. The tacheometer DEM was used as topographic input, and insolation was calculated for an estimated snow-free time 
span of 90 days between 1 June and 30 August 2008. The radiation in the investigated Artic region is usually highest during this time and low before and after, when the Sun's angle is lower. Furthermore, snow is usually melting by the end of May and starts to accumulate in September [e.g., Williams and Smith, 1989; Boike et al., 2008].

[16] Thermal infrared (IR) data acquired by Landsat ETM+ (Band 6, 10.4-12.5 $\mu \mathrm{m}, 60 \times 60 \mathrm{~m})$ were used to analyze spatial patterns of thermal emittance within the thermokarst depression and to extract at-sensor brightness temperatures for relative estimations of seasonal surface temperature differences within the thermokarst depression. An algorithm presented by Chander et al. [2009] was used to convert at-sensor spectral radiance to temperature. Averaged at-satellite temperatures were extracted for thermokarst depression slopes from 250 random points on five images acquired from June to September during the 2000 2002 period. One image acquired in June 2001 features cloud cover in the northeast of the thermokarst depression. Therefore, points covering this area were not included.

\subsection{Martian Data}

[17] Comparative analyses of the Martian scalloped depression were done using High-Resolution Imaging Science Experiment (HiRISE) data [McEwen et al., 2007] and Context Camera (CTX) data [Malin et al., 2007] from the Mars Reconnaissance Orbiter (MRO). HiRISE provides data with a very high spatial resolution of $30 \mathrm{~cm} /$ pixel and the possibility of 3-D views by stereo pairs. About 30 surveyed HiRISE images of UP contained possible Martian ground ice degradation features; the stereo pair PSP_001938_2265 and PSP_002439_2265 was selected for detailed analyses because these images contain large scalloped depressions representative of the UP region. Further topographic information was derived from a DEM of $1 \mathrm{~m} /$ pixel based on this stereo pair [Kirk et al., 2008] and MOLA tracks [Smith et al., 2001]. The CTX image P02_001938_2263, with a spatial resolution of about $6 \mathrm{~m} / \mathrm{pixel}$, was used for albedo estimations of the study site. Brightness temperatures for the selected region were derived from Thermal Emission Imaging System (THEMIS) infrared data [Christensen et al., 2004]. All data were stored in a geographical information system (GIS), processed in sinusoidal projection with a center longitude of $90.0^{\circ} \mathrm{E}$, and used for manual mapping of scalloped terrain.

[18] In order to investigate the insolation and resulting temperatures on the scalloped terrain, especially on the depression slopes, in the region under investigation, a 1-D thermal model was employed, which includes the effect of surface slopes, as described by Bauch et al. [2009]. The model was originally used to determine temperatures on the lunar surface and has been modified to fit Martian conditions with boundary conditions similar to the model by Kieffer et al. [2000]. Absorption and scattering in the atmosphere depend on the optical depth $(\tau=0.5)$, singlescattering albedo $(\omega=0.9)$, and an asymmetry dust factor $(G=0.7)$, for which we used parameters based on Viking and Pathfinder observations. On the basis of our CTX data an albedo of $A=0.16$ was chosen. According to Mellon et al. [2000] and Putzig et al. [2005], a thermal inertia of $I=300 \mathrm{~J} \mathrm{~m}^{-2} \mathrm{~s}^{-1 / 2} \mathrm{~K}^{-1}$ was assumed for the western UP region. The thermal conductivity was set to $1.6 \mathrm{~W} \mathrm{~m}^{-1} \mathrm{~K}^{-1}$, which corresponds to a fine-grained permafrost soil with a porosity of 40\% [Williams and Smith, 1989]. Insolation strongly depends on the planet's orbit; therefore, we used results from the work of Laskar et al. [2004] as input parameters for obliquity, eccentricity, and longitude of perihelion at different times in Martian history. Three scenarios were used to distinguish daily surface temperatures during summer (solar longitudes $L_{\mathrm{s}}=90^{\circ}$ ) on the gentle equator-facing scalloped depression slope, on the steep pole-facing scarp, and on a flat surface in the investigated region. In addition to the present insolation conditions, modeling was conducted for the most recent period of $35.0^{\circ}$ obliquity around $0.865 \mathrm{Ma}$ with an eccentricity of 0.059 and a solar longitude of perihelion of $309.5^{\circ}$ and the most recent period of $46.8^{\circ}$ obliquity around 5.641 Ma with an eccentricity of 0.03 and a solar longitude of perihelion of $141.2^{\circ}$.

\section{Results}

\subsection{Terrestrial Thermokarst Depression} Morphometry, Geomorphology, and Surface Features

[19] The DEM of the studied alas on Kurungnakh Island covers an area of $7.5 \mathrm{~km}^{2}$ and shows the mesoscale morphology of the investigated thermokarst depression in detail (Figure 4a). Several asymmetries are obvious from analyses of geomorphometric parameters, confirming observations made during the field work (Figure 5). Elevation, slope angle, aspect, and plan and profile curvature are used to identify and describe specific thermokarst depression properties. The depression is generally elongated in the N-S direction with a longitudinal axis of $3.3 \mathrm{~km}$ and a diagonal axis of $2.5 \mathrm{~km}$. About $28 \%$ of the depression area consist of slopes $>2^{\circ}$, with the west facing slopes occupying the largest area (Figure 4c). The thermokarst depression slopes clearly differ in their morphology and surface characteristics (Figure 5). The slope map (Figure 4b) indicates an asymmetrical shape in the NNW-SSE direction. While the steepest slope sections $\left(7^{\circ}-20^{\circ}\right)$ are prevalent on south and east facing slopes, the north and west facing slopes mostly show gentler slopes $\left(2^{\circ}-7^{\circ}\right)$ (Figure $4 d$ ). The south and southeast facing slopes in the north and northwest of the thermokarst depression (Figure $4 \mathrm{~b}$ ) and in the north of the small eastern lake (Lake 2 in Figure 4a) show the steepest slopes. These steepest slope sections are also represented by highly divergent (very convex) profiles on the upper slopes and highly convergent (very concave) profiles on the lower slope (Figures 6a and 7a). The slopes end sharply on the basin floor (Figure 5a).

[20] Concerning the relationship of slope steepness to instability, the high relief energy is further represented by high profile curvature values of the south and southeast facing slopes (Figures $6 a$ and $7 b$ ). These observations suggest a laterally directed thermokarst basin development. The west and north facing slopes and minor parts of the south and the east facing slopes are flat and more rectilinear (Figures $6 \mathrm{a}$ and $7 \mathrm{~b}$ ) and are characterized by less convexity in the upper slopes and less concavity in the lower slopes (Figure 7a). The comparatively low relief energy suggests higher slope and surface stability of the west and north facing slopes. The lack of denudation (i.e., areal erosion and slope retreat) is confirmed by the area-wide distribution of well-developed hummocks (about $40 \mathrm{~cm}$ high) and terrace- 

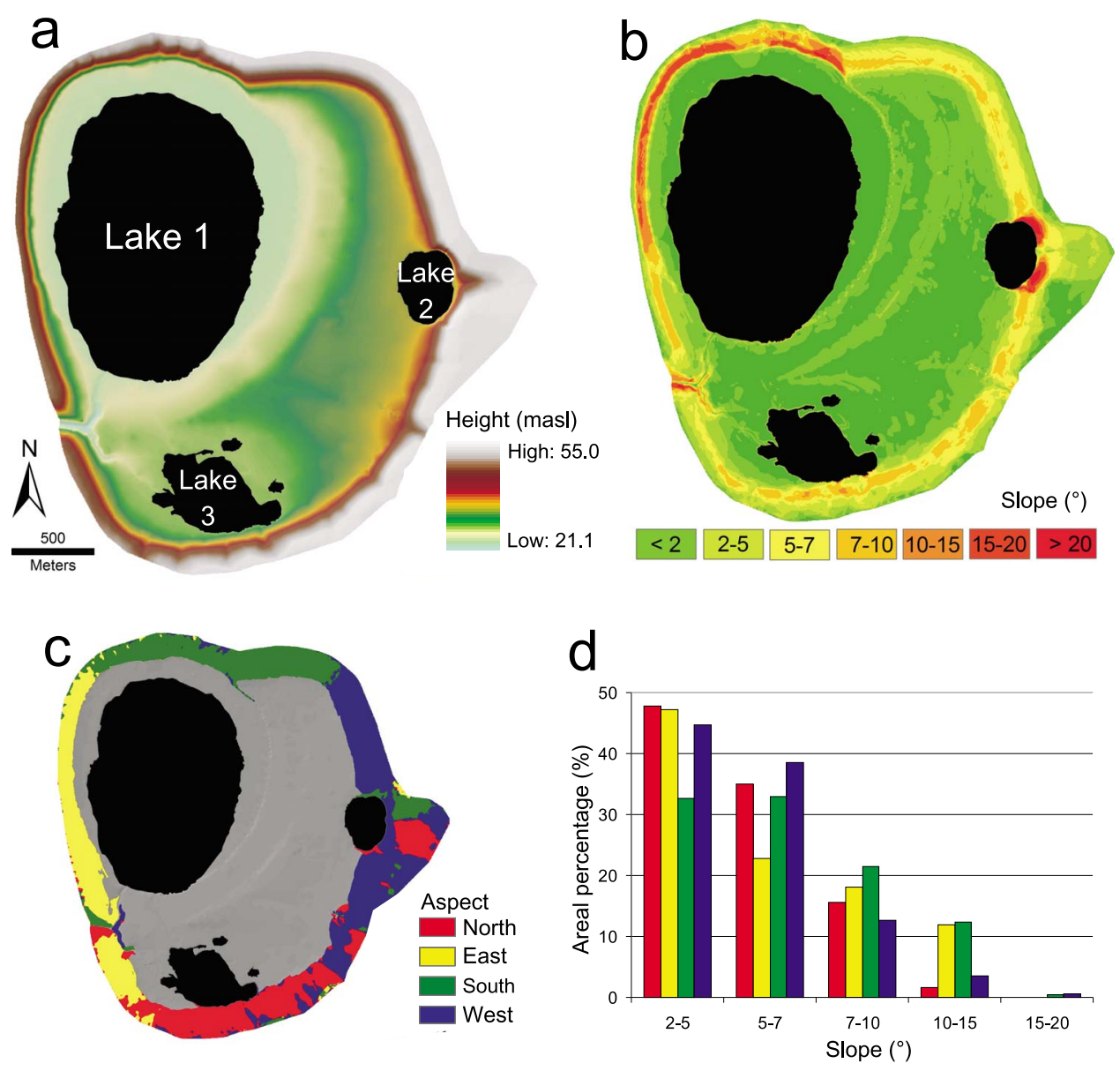

Figure 4. (a) DEM derived from tacheometric measurements (ground resolution 3m). (b) Slope map of the thermokarst depression. The asymmetrical shape resulting from the south/southeast exposure of the steepest slopes is obvious. Note that the lake terraces within the basin floor are subparallel and are elongated at the largest lake. (c) Aspect of the thermokarst depression slopes $>2^{\circ}$ and located $>30 \mathrm{~m}$ a.s.l. This mask was used for further calculations of slope properties. (d) Area of different slope exposure versus slope degree (color code same as that used in Figure 4c). The diagram shows that north and west facing slopes tend to be shallower. Steeper slopes are prevalent on south and southeast facing slopes, though east facing slopes differ in their profiles from the northern part (steeper) to the southern part (shallower) (see also Figure 5d).

like solifluction lobes (Figures 5b and 5c). These slopes are also distinguishable by a higher frequency of deep thermoerosional gullies, clearly visible in the planiform curvature map of the depression (Figure 6b). Despite minor parts of the south facing slope north of Lake 1, the other slopes are smoother in planiform curvature (Figure 6b).

[21] Slopes clearly differ in their vegetation cover and surface moisture (Figure 5). The generally drier south facing slopes are dominated by dwarf shrubs, lichens, and dry mosses. Hummocks are less pronounced here. In contrast, the southeast facing part of the western depression margin is covered by fresh green vegetation consisting of dwarf shrubs, grasses, and herbs. Tussocks of cotton grass beside mosses are abundant on the north and west facing slopes. The lower sections of these slopes are particularly affected by high surface moisture.

[22] The ice complex uplands surrounding the depression decrease in elevation from $55 \mathrm{~m}$ a.s.l. above the west facing slope to $37 \mathrm{~m}$ a.s.l. above the east facing slope. Different basin floor levels in the DEM are clearly obvious, indicating different stages of surface subsidence (Figure 4a). The basin floor is slightly inclined, from $28 \mathrm{~m}$ a.s.l. in the east to $21 \mathrm{~m}$ a.s.l. in the northwest, over three terraces, which are concentrically arranged around the largest lake (Lake 1), probably tracing former lake levels. The total thermokarst subsidence ranges from 27 to $16 \mathrm{~m}$ (mean $21.5 \mathrm{~m}$ ). The three large lakes within the thermokarst depression are located on different terrace levels. Lake 1 is located on the lowest level in the northwest of the depression, while Lake 2 is situated on the highest terrace level and Lake 3 on a middle level (Figure 4a). The former, probably N-S elongated elliptical shape of the alas is now interrupted by the basins of Lake 1 and Lake 2.

[23] According to field observations, the different terraces are clearly distinguishable in relief features, drainage situation, and vegetation. This is particularly obvious for the development of ice wedge polygonal structures. Oriented polygons on the shore of Lake 1 and on the slopes suggest 

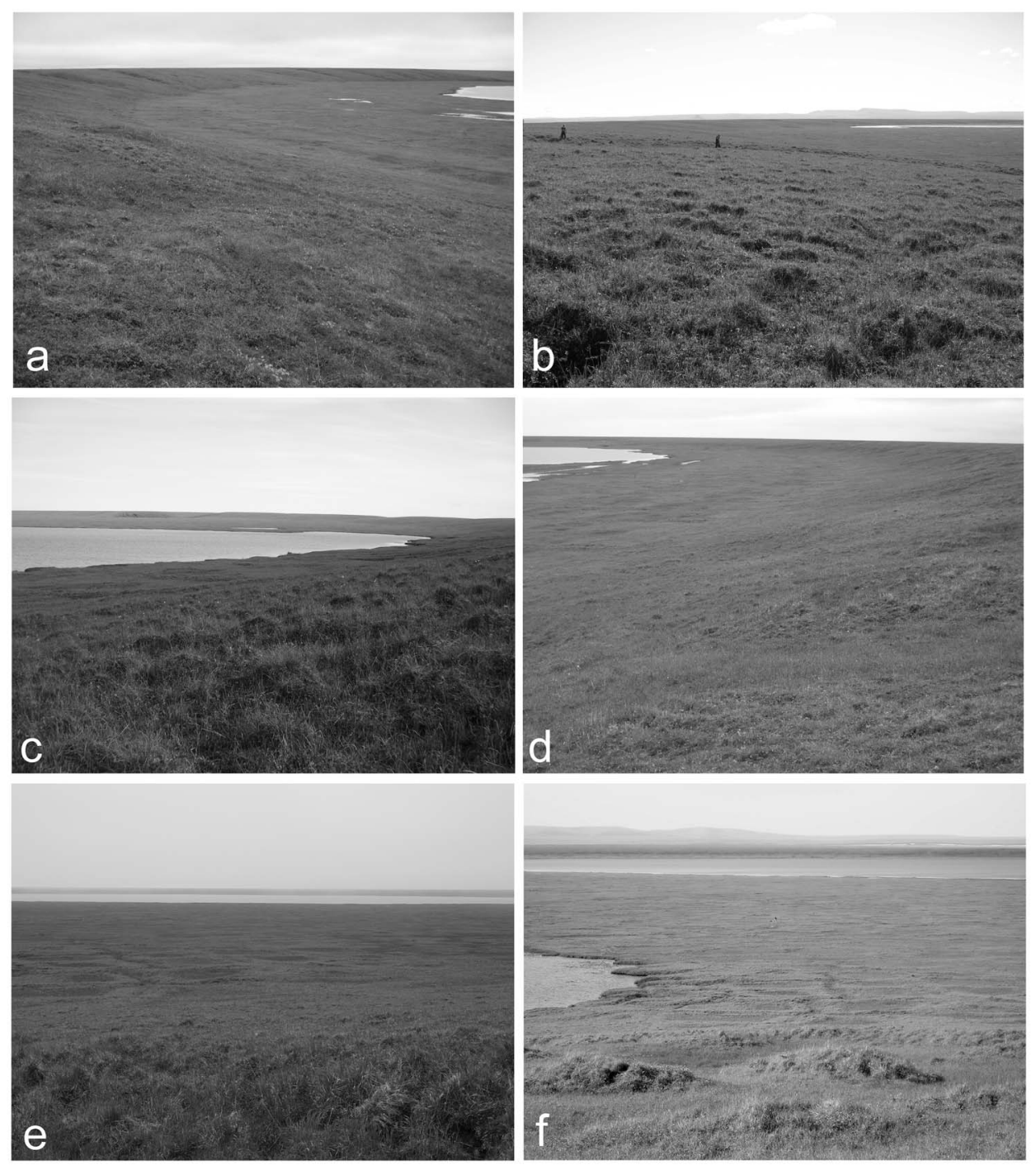

Figure 5. Surface characteristics of the differently exposed thermokarst depression slopes and examples of ice wedge polygons within the alas. (a) The steep south facing slope ends abruptly at the basin floor. View to the northeast. (b) Hummocky microrelief on the slightly inclined rectilinear west facing slope. View to the south. (c) View over Lake 3 to the east over the north facing slope which is characterized by hummocks and solifluction lobes caused by the poor drainage. (d) View to the south over the flattened southern part of the east facing slope. (e) Orthogonal low-centered polygons oriented on the south facing slope in the north of Lake 1. The polygonal microrelief is flatter toward the lake. View to the south. (f) Ice wedge degradation on the shore of Lake 2.

renewed ice wedge growth after the alas was formed (Figure 5e). Distinct orthogonal low-center polygons with diameters of about $20 \mathrm{~m}$ are randomly distributed over large parts of the highest basin floor level. Well-drained polygon rims, often covered by dwarf shrubs, are raised $\geq 50 \mathrm{~cm}$ above the centers. The centers are covered by moss and cotton grass and often contain polygonal ponds. Ice wedge degradation results in high-center polygons with deep troughs on the western shore of Lake 2 (Figure 5f) and at the mouth of larger thermoerosional valleys, which terminate in the thermokarst basin. Generally, the drainage degrades toward Lake 3 and Lake 1. The reduced microrelief of the polygons results in indistinct patterns with larger and commonly orthogonal (but sometimes pentagonal or hexagonal) polygons at some locations. While the very moist centers are covered by sedges, the hardly elevated rims are only distinguishable because the vegetation changes from sedges to peat mosses.

[24] Average active layer depths within the basin floor range between 36 and $82 \mathrm{~cm}$, with the deepest values occurring on the lowest basin floor level around Lake 1. Only small differences in active layer depth were measured between the different exposed slopes, where average depths are $38-49 \mathrm{~cm}$ on south and east facing slopes and $37-42 \mathrm{~cm}$ on west and north facing slopes. Differences in active layer depths seem to be caused by micromorphological conditions rather than by the aspect. Generally, smaller active layer depths occur in organic soils under insulating nonvascular 

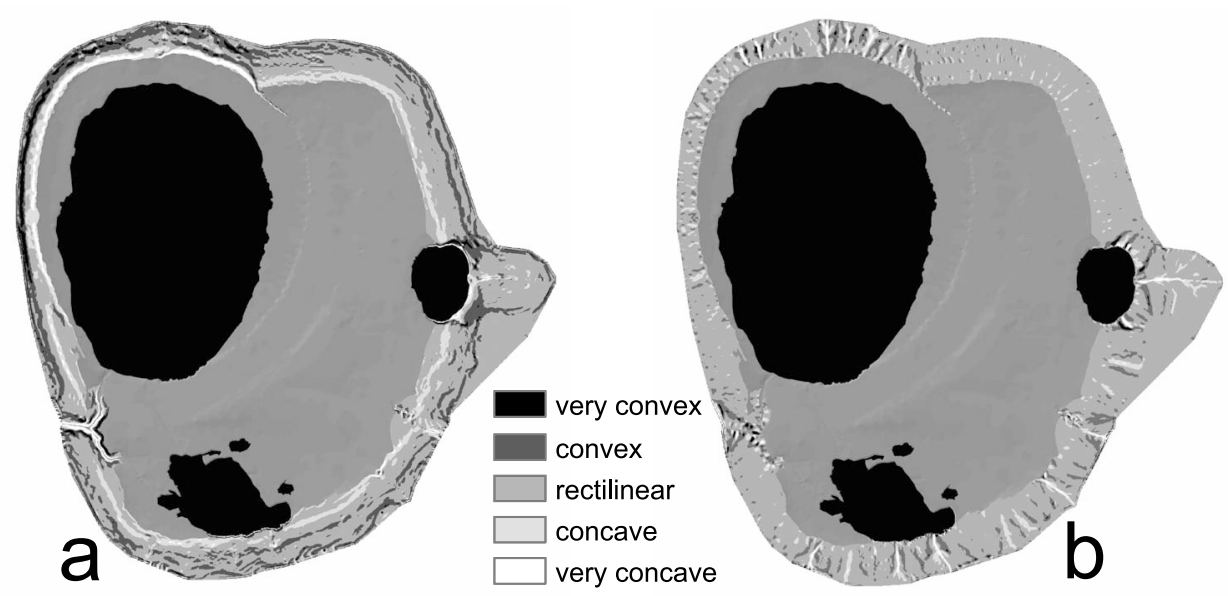

Figure 6. Curvature maps of the thermokarst depression slopes are calculated as the second derivative of the surface. The basin floor is not considered and is illustrated by the DEM shaded relief. (a) Profile curvature indicates the rate of potential slope gradient change. (b) Planiform curvature indicates the rate of aspect change along a contour.

vegetation (i.e., mosses and lichens) because the heat flux is reduced in summer, especially if these soils are dry [e.g., Williams and Smith, 1989; Anisimov and Reneva, 2006; French, 2007]. For instance, active layer depth within the moist center of low-center polygons located on the basin floor could be twice the depth on the rims. Drier and mostly flat high-center polygons show little differences in active layer depth between the center and the trough. On the slopes, differences occur especially in hummocky terrain. Average active layer thickness on the hummocks ranges from $46 \mathrm{~cm}$ on south facing slopes to $55 \mathrm{~cm}$ on east facing slopes. Between hummocks, depths range from $27 \mathrm{~cm}$ on west facing slopes to $35 \mathrm{~cm}$ on east facing slopes.

[25] Thermokarst depression development is related to massive surface subsidence. The depths of thermokarst depressions, and therefore, the amount of subsidence, are strongly related to the ground ice content. The sediment material in a thawing ice complex below a deepening thermokarst lake remains at the lake bottom as a taberal deposit (i.e., taberite) [e.g., Grosse et al., 2007] and could be exposed today, refrozen on the basin floor after the lake drained. Thus, the thickness of sediment remaining after an ice complex has thawed decreases if the ground ice content of the ice complex increases. Using the dimensions of the depression as extracted from the DEM and simple geometrical calculations of the base, top, height, and volume of an upside-down truncated cone, the thickness of taberal deposits can be estimated. An appropriate truncated cone for the investigated depression has a bottom radius of $1304 \mathrm{~m}$ and a top radius of $1518 \mathrm{~m}$ (Figure 8 ). Using the cut/fill tool of ArcGISTM, a lost volume of about $130.4 \times 10^{6} \mathrm{~m}^{3}$ was calculated, representing the volume of thawed ground ice. A corresponding cone height of $20.8 \mathrm{~m}$ was calculated $(\mathrm{H} 1 \mathrm{in}$ Figure 8), which accurately represents the mean depth of the thermokarst depression (see above) and therefore the current total thermokarst subsidence. The volume and thickness of the ice complex deposits previously existing at the site of the thermokarst depression can be calculated using different
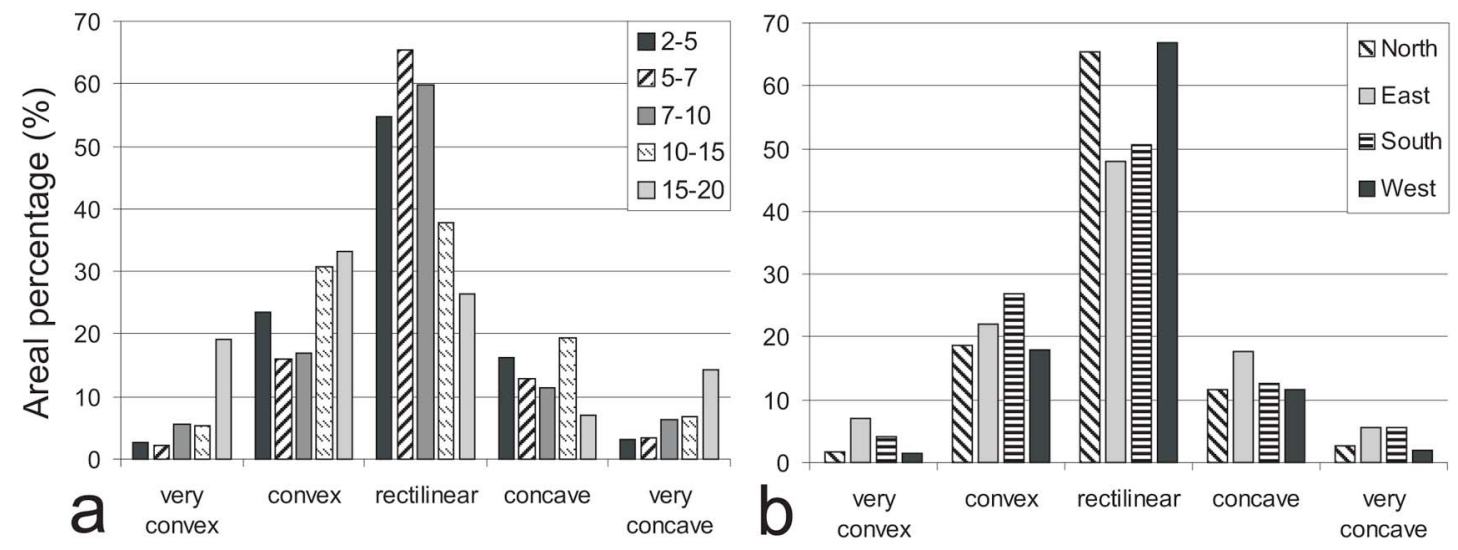

Figure 7. (a) A plot of the percentage area of different slope degrees versus profile curvature shows that the steepest slopes $\left(10^{\circ}-20^{\circ}\right)$ consistently exhibit higher convexity and concavity values. (b) a plot of the area of different slope exposures versus profile curvature indicate comparatively higher curvature values for south and east facing slopes and lower relief energy on north and west facing slopes. 


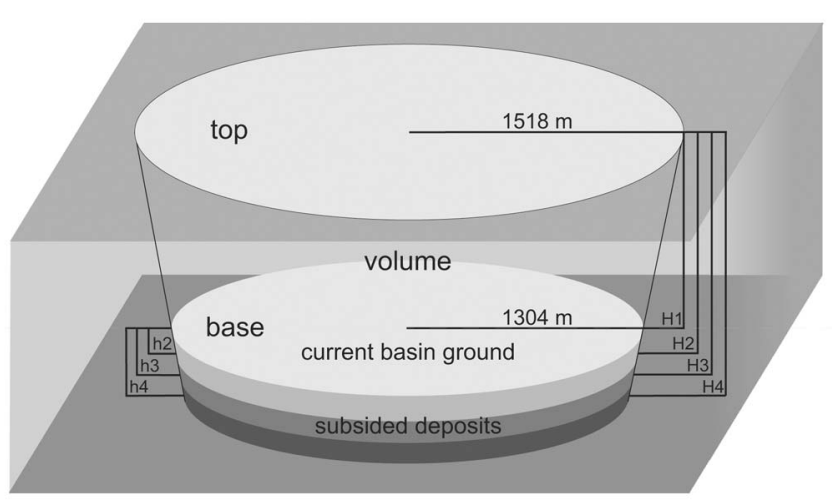

Figure 8. Geometrical representation of an upside-down truncated cone used for modeling subsided deposits (i.e., taberite), which is based on DEM data. Possible thicknesses of taberal deposits depending on ground ice contents are h2 for $90 \mathrm{vol} \%$, h3 for $80 \mathrm{vol} \%$, and h4 for 70 vol $\%$. Calculated cone height representing the current mean depth of the depression is given by $\mathrm{H} 1$. Ice complex thicknesses with different ground ice contents, which would have formerly existed to build the present thermokarst depression, are $\mathrm{H} 2$ with $90 \mathrm{vol} \%$, H3 with $80 \mathrm{vol} \%$, and H4 with $70 \mathrm{vol} \%$. Explanations: see text.

possible total ice complex ground ice contents $(70,80$, and $90 \mathrm{vol} \%$ ) arising from measured gravimetric ground ice contents of frozen sediments [Schirrmeister et al., 2003; Wetterich et al., 2008] and estimated contents of ice wedge and segregation ice. Calculated ice complex thicknesses which would have existed to build the present depression are shown in Figure 8. These are $23.1 \mathrm{~m}$ at $90 \mathrm{vol} \%(\mathrm{H} 2)$, $26.6 \mathrm{~m}$ at $80 \mathrm{vol} \%(\mathrm{H} 3)$, and $29.7 \mathrm{~m}$ at $70 \mathrm{vol} \%(\mathrm{H} 4)$. This would imply present taberite thicknesses of $2.3 \mathrm{~m}$ for $90 \mathrm{vol}$ $\%$ (h2), $5.2 \mathrm{~m}$ for $80 \mathrm{vol} \%$ (h3), or $8.9 \mathrm{~m}$ for $70 \mathrm{vol} \%(\mathrm{~h} 4)$. The most realistic calculations suggest 90 vol\% ground ice content, close to taberite thicknesses observed by Grosse et al. [2007]. However, accumulation of lake sediments, possible erosion of material, as well as the subaerial accumulation of sediments on the basin floor after lake drainage and/or peat formation after surface stabilization [Romanovskii et al., 2000; Grosse et al., 2007; Ulrich et al., 2009] cannot be ruled out.

\subsection{Insolation and Thermal Properties of Terrestrial Thermokarst Depression}

[26] Areas of high incoming radiation are clearly distinct from areas of low radiation in the solar insolation map of the thermokarst depression (Figure 9). Influences of the basin morphology are obvious. The south facing slopes are exposed to much higher radiation rates than the north facing slopes. West facing slopes show higher total rates than east facing slopes. Calculated radiation values over the modeled period range from $\sim 259 \mathrm{kWh} / \mathrm{m}^{2}$ (daily mean of $\sim 120 \mathrm{~W} / \mathrm{m}^{2}$ ) on south facing slopes to $\sim 193 \mathrm{kWh} / \mathrm{m}^{2}$ (daily mean of $\sim 89 \mathrm{~W} / \mathrm{m}^{2}$ ) on north facing slopes for the modeled time period between June and August (Figure 9). Furthermore, Figure 10 suggests the highest calculated radiation values occur at slope angles between $10^{\circ}$ and $20^{\circ}$ on the south facing slopes, while lower and medium values were generally calculated for lower degrees of slope $\left(2^{\circ}-7^{\circ}\right)$. In par- ticular, the highest radiation values correspond to the steepest south facing slopes north of both Lake 2 and Lake 1. Generally, these findings were confirmed by the field measurements (Figure 9). The highest downwelling shortwave radiation (averaging from 503 to $530 \mathrm{~W} / \mathrm{m}^{2}$ ) was measured on south facing slopes (Figure 9). Lower measurements were acquired on the east and north facing slopes (from 297 to $471 \mathrm{~W} / \mathrm{m}^{2}$ ). However, inaccuracies caused by varying measurement conditions and cloud cover correction potentially exist in the recorded data and must be considered.

[27] Additionally, the modeled insolation could be validated using Landsat ETM+ thermal data (Figure 11). Soil surface temperatures are related to environmental conditions such as solar radiation, snow cover, and/or prevailing wind. Furthermore, they are important in determining morphological conditions on Arctic slopes [e.g., French, 1970]. The seasonal temperature variations clearly differ on different slopes of the thermokarst depression (Figures 11a-11e). Temperatures are always highest on south facing slopes and lowest on north facing slopes. In addition, higher values were derived on the west than on the east facing slopes between July and August (Figure 11f). In absolute terms, the highest temperatures were reached at the beginning of August. A strong temperature increase could be observed from June to July and a comparable decrease from August to September. This correlates with the general regional temperature pattern [Boike et al., 2008]. The derived relative temperatures decrease to near $0^{\circ} \mathrm{C}$ in September on parts of the north facing slopes (Figure 11e). Only the south southeast facing slope shows higher temperatures at this time. Thus, the temperature distribution on the thermokarst depression slopes is consistent with the modeled solar insolation.

[28] The scatter plots in Figure 12 show Landsat-derived temperatures for 250 random points versus modeled solar

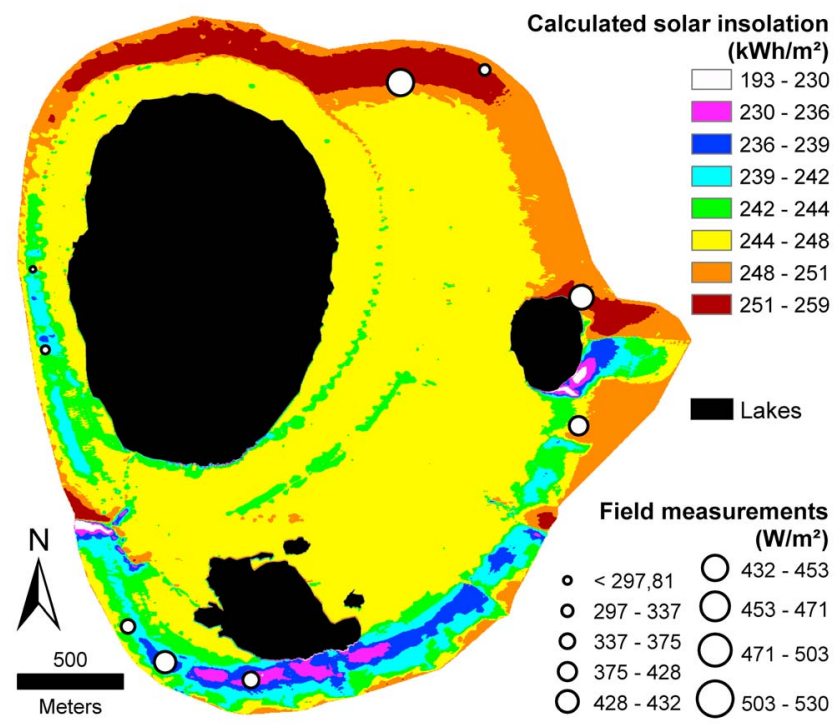

Figure 9. The relationship of calculated solar insolation to thermokarst depression topography is shown as the amount of radiation between 1 June and 30 August 2008. At each location, downwelling shortwave radiation field measurements are shown as instantaneous values. 


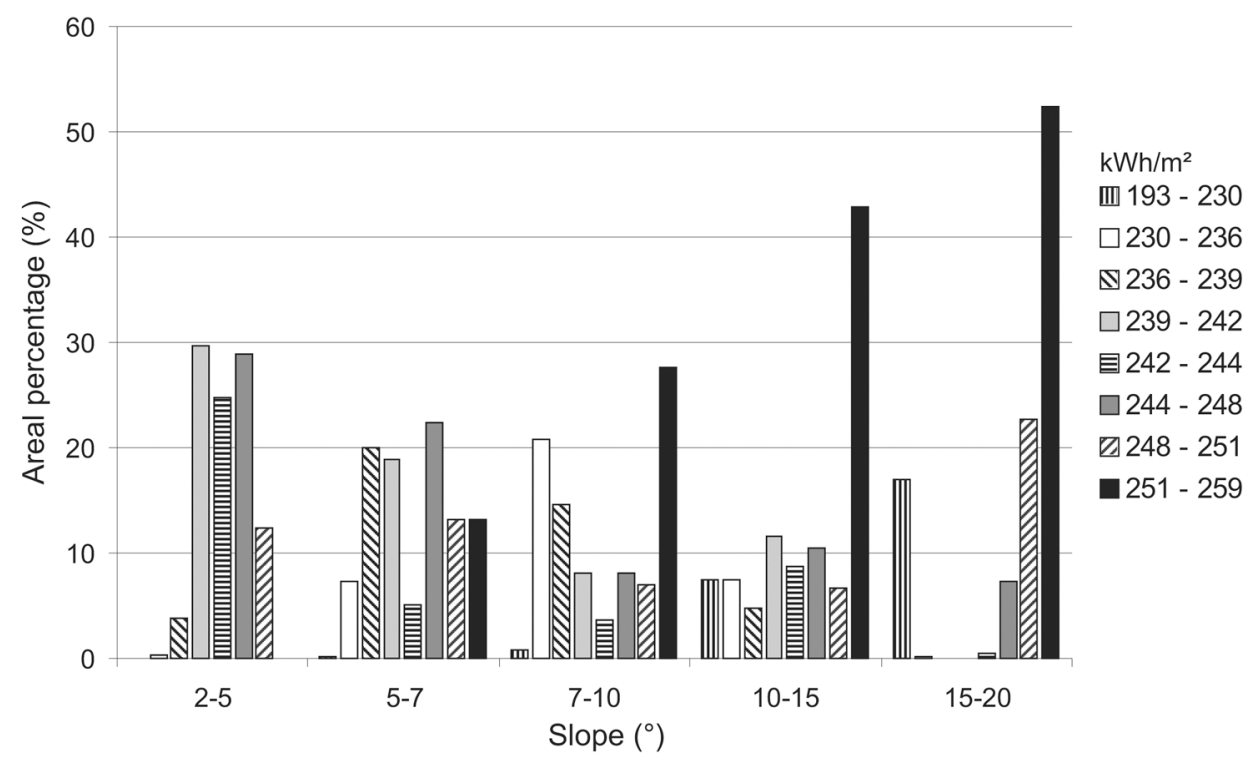

Figure 10. Relationship between degree of slope and modeled solar radiation. Highest insolation values are clearly related to steepest slopes. Amounts of insolation $\left(\mathrm{kWh} / \mathrm{m}^{2}\right)$ are equal to those found in Figure 9.
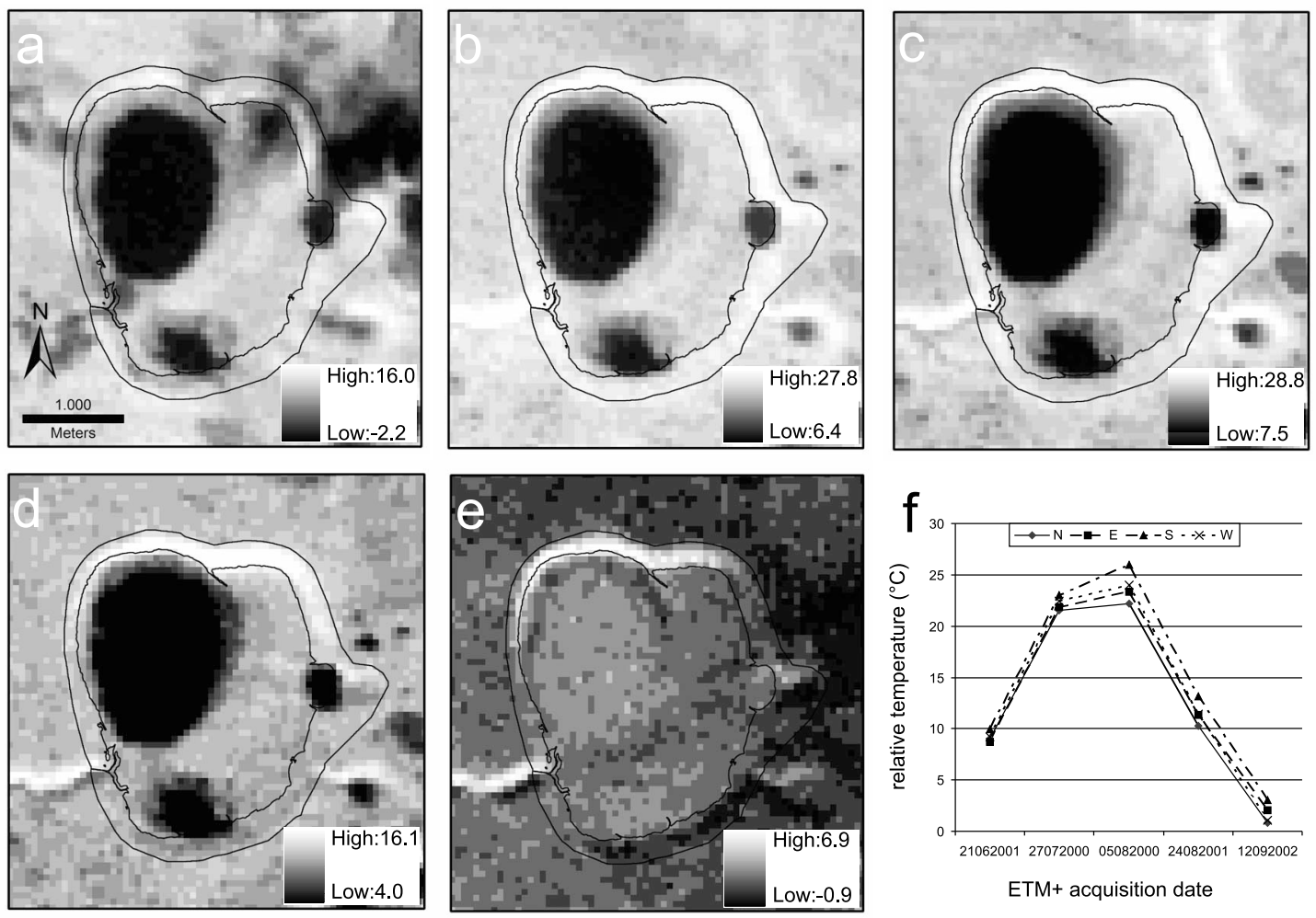

Figure 11. Changes over time in Landsat ETM+ thermal data (Band 6, 10.4-12.5 $\mu \mathrm{m}, 60 \times 60 \mathrm{~m}$ ) for the investigated thermokarst depression. Temperatures in ${ }^{\circ} \mathrm{C}$ (see legends on the bottom right of each panel) are only relative, derived after Chander et al. [2009] and should not be seen as absolute values. Black outlines mark the area of basin slopes. Acquisition dates and times: (a) 21 June 2001, 3:17 UTC; (b) 27 July 2000, 3:25 UTC; (c) 05 August 2000, 3:18 UTC; (d) 24 August 2001, 3:16 UTC; (e) 12 September 2002, 3:15 UTC. (f) Temperature trend for the different slope exposure extracted and averaged from randomly distributed points. 


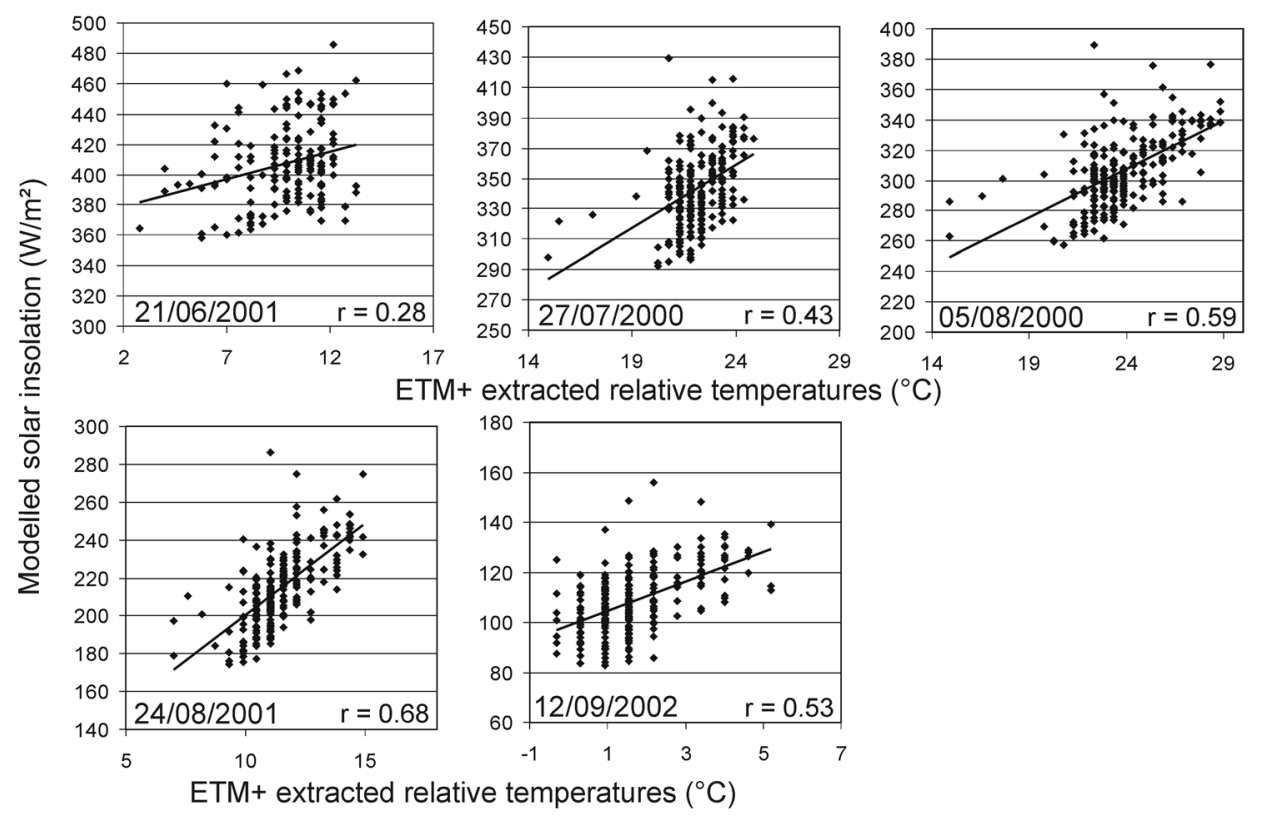

Figure 12. Landsat ETM+ extracted temperatures versus modeled solar insolation. The correlation coefficient $(r)$ and the satellite acquisition date are shown for each plot. The solid line indicates the 1:1 line. Note the different axis scales corresponding to the seasonal temperature conditions.

insolation. Insolation data were modeled on each point for an hour around the acquisition time and date of the satellite imagery. The correlation coefficients shown for each plot indicate moderate to good correlations, particularly for August and September. The best fit was derived for 24 August 2001 (Figure 12). Temperature differences within the thermokarst depression are probably most connected to varying insolation in late summer. However, the influence of DEM-measured topography during insolation modeling must be considered, because the complex surface conditions are only partly reflected in the comparatively low-resolution Landsat at-satellite temperatures. This is particularly obvious in the scatter plots where the modeled insolation varies for points with equal temperatures. The highest variations and therefore the lowest correlation coefficients are observed for 21 June 2001 (Figure 12). Insolation is typically highest during June, but soil-surface temperatures are comparatively low in early summer [Boike et al., 2008]. Finally, the control of temperature by geomorphology and seasonal differences between the slopes become obvious in the Landsat satellite data.

\subsection{Morphological Properties of Scalloped Depressions on Mars}

[29] The morphology of scalloped depressions has been described by numerous authors for the northern [e.g., Morgenstern et al., 2007; Soare et al., 2007, 2008; Lefort et al., 2009] and southern [e.g., Lefort et al., 2010; Zanetti et al., 2010] hemispheres of Mars. Thus, the studied area in western UP (Figure 3) is representative and was primarily selected for comparison to the terrestrial investigation area (Figure 2). About 38\% of the UP area is characterized by the formation of scalloped terrain (Figure 3b) and consists of typical rimless, irregularly shaped depressions (Figure 3c). The size of single isolated depressions ranges from an area $\sim 0.004 \mathrm{~km}^{2}, 80-100 \mathrm{~m}$ in diameter, to an area of $\sim 2 \mathrm{~km}^{2}$, $1-2 \mathrm{~km}$ in diameter. The mapped area of the largest complex of coalesced scalloped depressions covers $68 \mathrm{~km}^{2}$, though further expanding outside the mapped area. Smaller isolated depressions are generally bowl-shaped and completely surrounded by more-or-less steep slopes (Figure 13a). Depths extracted from HiRISE DEM data [Kirk et al., 2008] (Figure 13) are on average $\sim 5 \mathrm{~m}$. Larger single depressions in the study area are 20-25 m deep and show the typical north-south asymmetrical shape with steep and always concave-upward north (pole) facing slopes, and gentle convex-to-concave south (equator) facing slopes (Figures $13 \mathrm{~b}$ and $13 \mathrm{c}$ ). DEM-derived slope angles are $10^{\circ}-30^{\circ}$ for the steep pole-facing scarps and typically $2^{\circ}-4^{\circ}$ for the opposite, gentle slopes. The floors of larger isolated depressions and complexes of coalesced depressions are characterized by curvilinear step-like ridges, which are elongated subparallel to the steep scarps; these ridges exhibit asymmetrical profiles, with the steeper side facing the scarp. The number of ridges increases with the size of the depression (Figure 13), which was interpreted by Lefort et al. [2009] to reflect different stages of scarp retreat. The coalescence of the depressions to scalloped terrain is influencing large areas in UP (Figure 14). Coalescing scallops extend over different elevation levels (Figure 14a). Convex slope breaks are typical of the interfaces between coalesced scallops (Figure 14b). Interdepression areas are characterized by a multiphase lowering without any incision [Balme and Gallagher, 2009]. No channels have been observed that would connect separate scalloped depressions. On Mars, they have only been found in association with much older, Hesperian-aged thermokarst depressions [Warner et al., 2010].

[30] The region is characterized by distinct polygonal patterned ground [e.g., Lefort et al., 2009; Levy et al., 2009]. The scalloped terrain is well defined from the adjacent 

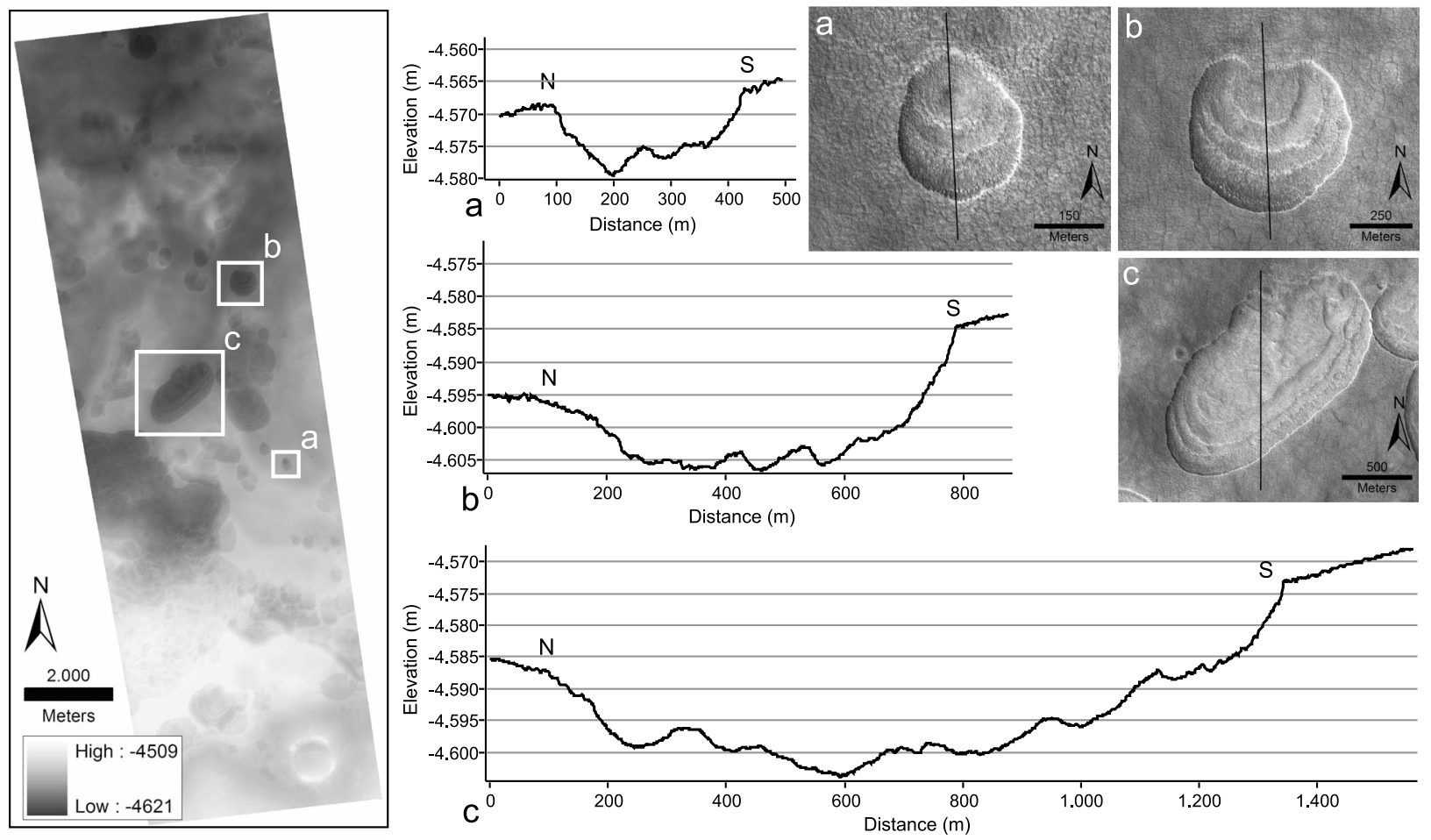

Figure 13. HiRISE DEM ( $1 \mathrm{~m} / \mathrm{pixel}$, stereo pair: PSP 001938 2265 PSP_002439 2265) showing the location of typical single-scalloped depressions in the investigated Martian area that reflect different stages of scallop development. (a) Small, fairly symmetrically shaped depression shows one or two ridges. (b) Medium-sized scalloped depression with very steep concave north facing slope and slightly inclined convex south facing slope. Three distinct ridges are visible. (c) Large depression with a flattened profile. The slope asymmetry is visible. Four curvilinear ridges exhibit a step-like profile.

nondegraded uplands by the type of polygonal structures. The uplands show comparatively large irregular random orthogonal polygons. HiRISE data indicate mean diameters of $40-60 \mathrm{~m}$ (Figure 15). The flat to slightly elevated centers are surrounded by well-pronounced and partly deepappearing troughs. These polygonal structures seem to be truncated by scallop development. Troughs are often traceable over the scarps but disappear toward the deeper parts of the depression. In contrast, inside the scalloped depressions there are orthogonal high- to low-center polygons, which are almost $10 \mathrm{~m}$ in mean diameter (Figure 15). The strong orientation of polygons parallel to steep north facing slopes is noteworthy; this might be caused by primary cracking perpendicular to the scarp front. The distinct character of the polygonal structures inside and outside of scalloped depressions suggests remarkable differences in ground and atmospheric conditions during polygon formation, as has been explained for terrestrial regions by, e.g., Lachenbruch [1962, 1966], Yershov [2004], and French [2007].

\subsection{Insolation and Thermal Properties of Scalloped Depressions Within the Martian Mantle Terrain}

[31] Lefort et al. [2009] and Zanetti et al. [2010] have suggested that temperature differences between the north and south facing slopes of the Martian scallops result in enhanced heating of the equator-facing slopes. Therefore, previous interpretations were focused on enhanced scallop development at these slopes [Morgenstern et al., 2007;
Lefort et al., 2009, 2010; Zanetti et al., 2010]. Three THEMIS-IR images from the Mars Odyssey orbiter [Christensen et al., 2004] covering a time period from early spring to middle summer show seasonal temperature variations in the study area (Figures 16a-16c). The temperature changes over time demonstrated in the THEMIS-IR show that the uplands warm at a remarkably faster rate than does the scalloped terrain, allowing the scalloped depressions to be distinguished from the uplands by their lower temperatures (Figures 16a-16c and 16e). Temperature differences within the scallops on the depression slopes are relatively low though all images are acquired at local solar times (LST) in the afternoon. In early spring $\left(L_{\mathrm{s}}=21.95^{\circ}, \mathrm{LST}=\right.$ 17.07), temperatures range from $\sim 203 \mathrm{~K}$ within the depressions to $\sim 227 \mathrm{~K}$ on exposed upper slopes and the adjacent uplands (Figure 16a). In late spring $\left(L_{\mathrm{s}}=75.58^{\circ}\right.$, LST $=$ 17.83 ), temperatures have already reached $\sim 239 \mathrm{~K}$ on the adjacent uplands (Figure 16b); these temperatures are not exceeded in middle summer (Figure 16c). During summer $\left(L_{\mathrm{s}}=130.27^{\circ}, \mathrm{LST}=17.82\right)$, only the steeper upper parts of the exposed slopes, passing into the uplands, are warmer (by about $2 \mathrm{~K}$ ) than the opposite slope and the areas within the scallops (Figure 16c). However, the temperature range is greater in spring ( $\sim 215$ to $\sim 239 \mathrm{~K})$ than in summer ( $\sim 224$ to $\sim 237 \mathrm{~K}$ ).

[32] CTX-derived albedo further indicates a distinct contrast between the depressed scalloped terrain and the nondegraded uplands. The higher albedo within the scalloped 


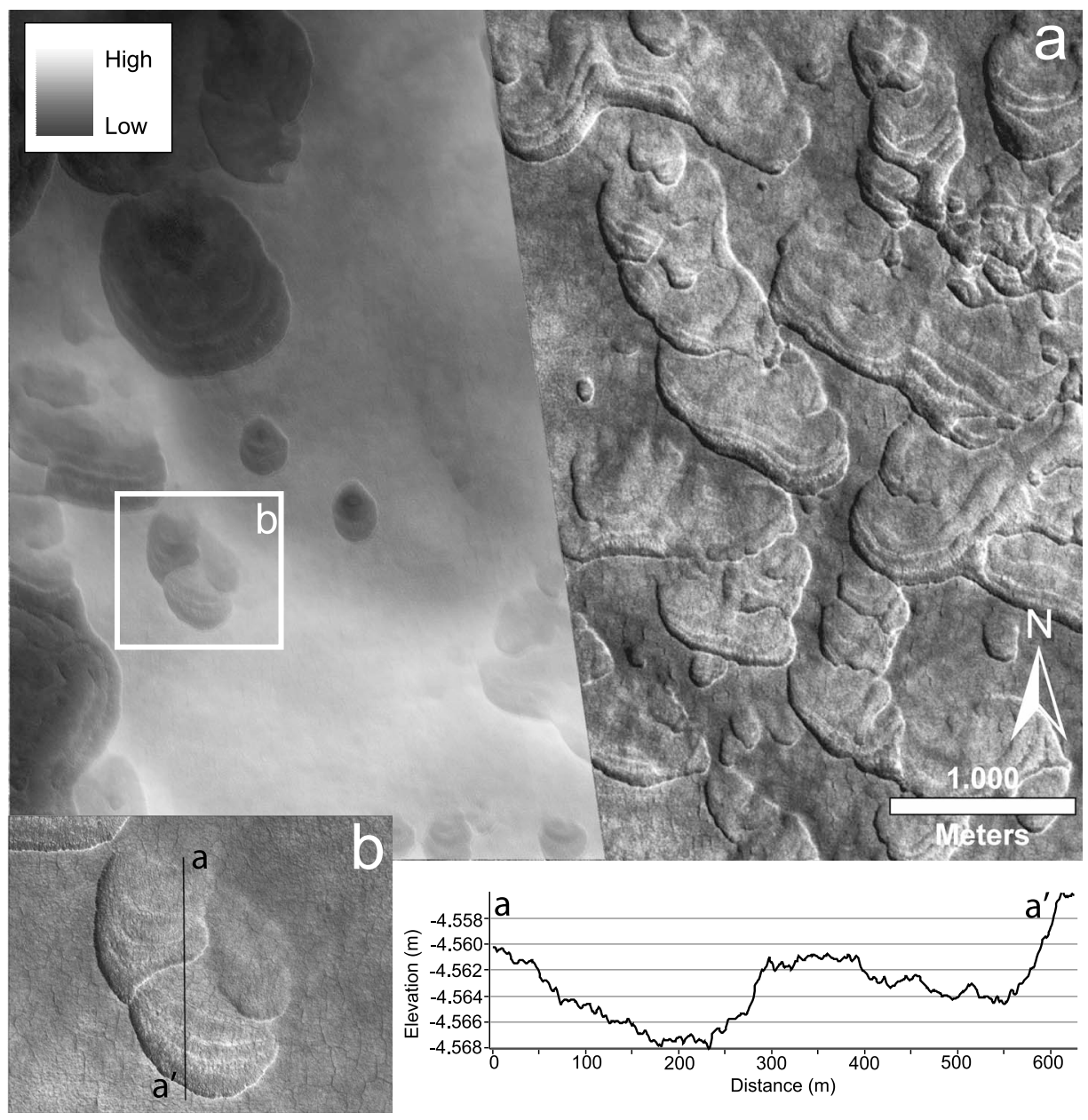

Figure 14. (a) Scalloped terrain in the investigated area in Utopia Planitia resulting from the coalescences of scalloped depressions by areal expansion. Smaller isolated depressions in different stages of development are visible nearby (part of the HiRISE DEM on CTX image subset P02_001938_2263_XI_46N267W). (b) An example of small coalesced scalloped depressions and the DEM derived topographic profile highlight a multiphase lowering without connecting channels.

terrain (Figure 16d) suggests different thermal properties of the material inside the depressions and on the adjacent uplands. Nighttime THEMIS-IR data showing the higher temperatures of the nondegraded uplands during night (Figure 16e) confirms this assumption. The more compact and (judging by the albedo; Figure 16d) darker material of the uplands would possess higher thermal inertia (i.e., the ability of material to store and conduct heat) than the more unconsolidated fine-grained material within the depressions [e.g., Mellon et al., 2000; Putzig et al., 2005]. Accelerated warming of the nondegraded uplands caused by the general exposure of the area can be ruled out because the area gently rises toward the south.

[33] Generally, the results from insolation modeling (Figure 17) suggest that the typical asymmetric morphology of the scalloped depressions and their formation can be explained by variations in Mars' orbital parameters. During present orbital configurations, maximum daily surface temperatures on the gentle, equator-facing slopes of the scallops are permanently higher than on the steep polefacing scarps, due to the higher insolation (Figure 17a). In the case of increasing obliquity (i.e., $35^{\circ}$ and more), temperature differences between the slopes remain relatively constant but absolute temperatures increase and exceed the melting point of water with certainty only on the equatorfacing slopes and flat surfaces (Figure 17b). Over periods of high obliquity $\left(>45^{\circ}\right)$, the results show that the pole-facing slopes receive higher insolation than the equator-facing slopes, and temperatures are higher in the morning and evening hours (Figure 17c). During the day, temperatures on the pole-facing scarps and the equator-facing slopes are equal and range from well above to right at the melting point of water. The modeling was tested for varying orbital configurations as well. Temperatures on all surfaces can be noticeably higher if high obliquity coincides with high eccentricity, especially if the Martian Northern Hemisphere summer coincided with perihelion at the same time. The results are similar to results mentioned by Paige [2002]. For instance, for a period around $4.816 \mathrm{Ma}$ with an obliquity of $34.8^{\circ}$ and a high eccentricity of 0.10 the temperature differences between the slopes are similar to the scenario presented in Figure 17b, but absolute temperatures are $10 \mathrm{~K}$ 


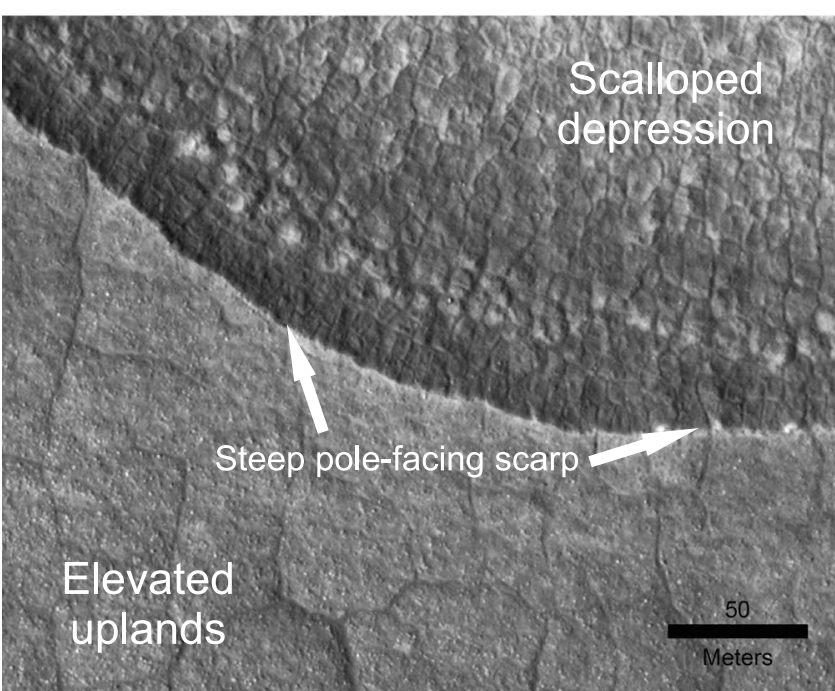

Figure 15. Example of polygonal patterned ground inside the scalloped depressions and on the adjacent uplands (HiRISE image subset: PSP_001938_2265).

higher on all slopes and exceed the melting point of water on the pole-facing slopes as well as on the equator-facing slopes. Otherwise, for a period around $9.112 \mathrm{Ma}$ with a high obliquity of 46.3 and higher eccentricity of 0.08 , comparable to the scenario presented in Figure 17c, temperatures were around $10 \mathrm{~K}$ lower because the solar longitude of perihelion was far from the summertime at this time. However, these specific orbital configurations have rarely occurred during the last $20 \mathrm{Ma}$ [Laskar et al., 2004].

\section{Discussion}

\subsection{Terrestrial Characteristics of Slope Asymmetry and Spatially Directed Thermokarst Development}

[34] The morphometric analyses on Kurungnakh Island confirm a spatially directed thermokarst development process in ice-rich deposits, as already postulated using remote sensing analysis [Morgenstern et al., 2008a]. On the basis of the general basin form, the slope asymmetry, and the lake configuration as well as the lake terrace arrangement (Figure 4a), a lateral thermokarst development in a northern direction is hypothesized. The results suggest solar insolation (Figure 9) and surface temperatures (Figure 11) as crucial factors controlling thermokarst slope instability and steepness. The highest amounts of solar insolation and the highest temperatures on south facing slopes force lake migration in a northern direction and therefore the lateral orientation of thermokarst development. In the case of the investigated thermokarst depression, Lake 1 interrupts the former contour of the thermokarst basin, which probably was regularly elliptical. Furthermore, Lake 2 is propagating into the slope, probably in a northern direction as well.

[35] The steepness of the south and southeast facing thermokarst depression slopes indicates the geomorphological activity. Denudative processes (i.e., solifluction) have not yet resulted in a flattening of these slopes, as has happened on the west- and north facing slopes where the widespread distribution of hummocks suggests slope stability. The slope instability of steep south and southeast facing slopes is also indicated by the high relief energy represented by the high profile curvature of these slope sections (Figures 6a and 7). Slope retreat and subsidence probably dominates thermoerosional gully formation here, as seen in the planiform curvature map (Figure 6b). The field observation of an area (several square meters in size) on the south facing slope north of Lake 2 with disturbed vegetation and slope movement, comparable to retrogressive thaw slumps, supports these assumptions, and clearly reflects the present slope instability (Figure 18). Furthermore, spatial and temporal analyses of remote-sensing data show a retreat rate of the south and southeast facing slopes of a few centimeters per year north of Lake 1 during the last 40 years [Günther, 2009] and a measurable shift (by a few meters) of Lake 1 and Lake 2 to the north.

[36] Differently exposed slopes receive varying amounts of radiation. Only small differences in active layer depth $(<7 \mathrm{~cm})$ as a function of aspect were observed. If the heat transfer to the ground varies as a function of slope and aspect, then these variations result in thawing of ice complex deposits at the base of the active layer and in subsidence of the ground surface, rather than in variable thaw depths [Overduin and Kane, 2006].

[37] Generally similar observations supporting our work were made by Czudek and Demek [1970] for large thermokarst depressions in Central Yakutia (Siberia), where south facing slopes are commonly steeper because erosion is more effective there and the slopes are thawed to greater depths. In contrast, as was observed in our study as well, north facing slopes are moister and more gently inclined. A possible control of spatial thermokarst development by insolation has been mentioned by several Russian authors, although no quantitative validations were presented. Soloviev [1962] explains the elongation of thermokarst basins in northern and eastern directions by more intense warming and erosion of slopes exposed to the south and west. Boytsov [1965] also points out the influence of direct solar radiation on the pace of thermoabrasion of differently exposed slopes. In general, south southwest facing slopes receive the highest energy as air and water temperatures are highest during times when the afternoon sun is directed at these slopes. Thermoabrasion is more pronounced here and accounts for an elongation of a thermokarst lake basin in north northeastern directions. This pattern can be altered by the severe morning fog or afternoon cloud cover typical for some regions, which will have a weakening effect on slope warming and lateral basin growth.

[38] Steep head-wall retreat and retrogressive thaw-slump activity mainly forced by solar radiation and sensible heat flux were identified by Lewkovicz [1986] and recently confirmed by Grom and Pollard [2008] using microclimatic investigations on a southerly oriented active thaw slump in the Canadian high Arctic. Insolation as primary agent of slope asymmetry in Artic asymmetrical valleys was already suggested by Crampton [1977], who described steeper south facing slopes in numerous asymmetrical valleys in the Mackenzie River region of Canada. Similar observations were made by French [1970]. The steepness of southwest facing slopes was explained by higher loss of latent heat due to the exposure of these slopes to prevailing winds and thus warmer and moister conditions on the opposite slopes. These conditions result in a higher extent of mass-wasting 

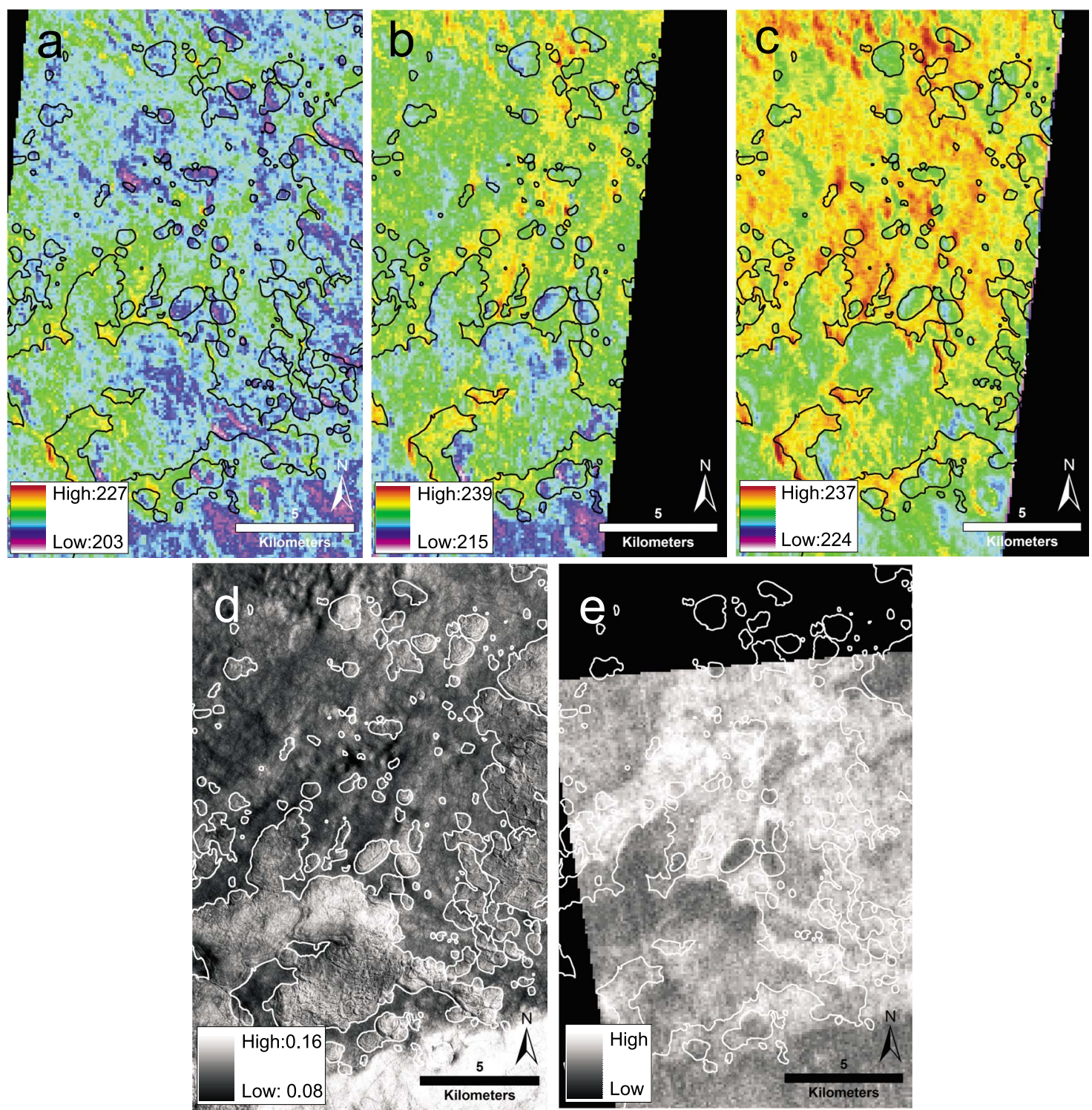

Figure 16. $(\mathrm{a}-\mathrm{c})$ Daytime temperature variations for the investigated Utopia Planitia area from early spring to middle summer. The changes over time show that the undegraded uplands warm faster than the scalloped terrain (black outlines). Temperatures are given in Kelvin. (a) Early spring (THEMIS-IR image I27105029, LS: 21.95 LST: 17.07). (b) Late spring (THEMIS-IR image I28565002, LS: 75.58 LST: 17.83). (c) Summer (THEMIS-IR image I21689005, LS: 130.27 LST: 17.82). (d) CTX-derived albedo (Lambert albedo) indicates a distinct contrast between the scalloped terrain (white outlines) and the adjacent uplands (CTX image P02_001938_2263_XI_46N267W). (e) The higher nighttime temperatures of the undegraded uplands are clearly visible (THEMIS-IR image I03386003, LS: 70.28 LST: 4.24).

(solifluidal) processes on northeast-facing slopes, where material is preferentially transported into the river and the streams are therefore pushed to the southwest-facing slopes. In response, the slope is undercut and steepened. It must be noted that theories of asymmetrical valley development are difficult to apply to thermokarst slope asymmetry, because erosion and accumulation processes of a flowing river are of prime importance. However, the influence of ponding water on thermokarst depression development must be considered [e.g., Czudek and Demek, 1970; Romanovskii et al., 2000]. The most effective process is the lateral bank erosion of a standing water body. Wind has been suggested as the driving agent of oriented thaw lake expansion due to winddriven currents and wave activities [e.g., Carson, 2001; Côté and Burn, 2002; Hinkel et al., 2005; French, 2007]. However, great differences exist in wind data from several meteorological stations within the Lena Delta area, and there is little knowledge about the detailed conditions and factors that might be involved in lake-orientation processes in the Delta [Morgenstern et al., 2008b].

[39] According to Soloviev [1973] and Romanovskii et al. [2000], the following scenario of landscape evolution at our thermokarst study site can be proposed: An approximately north-south elongated depression was filled and formed by a 

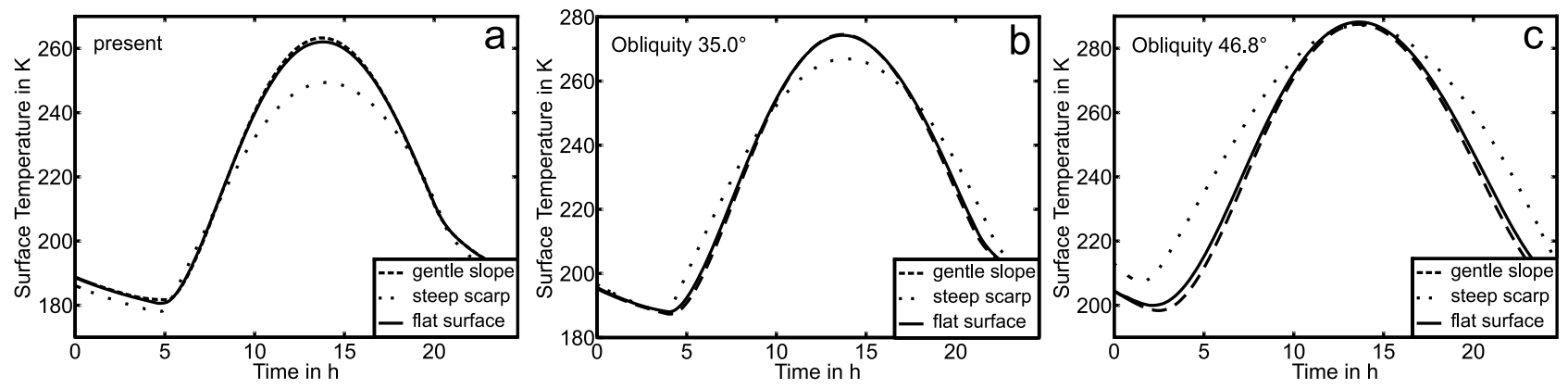

Figure 17. Modeled maximum daily surface temperatures during summer (LS: $90^{\circ}$ ) in the investigated region in western Utopia Planitia for a $20^{\circ}$ pole-facing scarp, a $3^{\circ}$ equator-facing slope of a scalloped depression, and a flat surface. Temperatures are calculated for three orbital configurations (obliquity, eccentricity, and longitude of perihelion) according to Laskar et al. [2004]. (a) Present insolation conditions; obliquity: $25.2^{\circ}$, eccentricity: 0.09 , longitude of perihelion: 251.0. (b) Insolation conditions at $0.865 \mathrm{Ma}$. (c) Insolation conditions at 5.641 Ma.

large thermokarst lake in an early stage during the late Glacial to early Holocene period. The fast-growing thermokarst lake thawed and deepened into the ice-rich deposits beneath, resulting in strong thermokarst subsidence [Grosse et al., 2007]. Taberal deposits remaining at the lake bottom probably range in thickness from 2.3 to $8.9 \mathrm{~m}$ today. The current volume and dimension of the thermokarst depression accurately reflects the high-ground ice content, as was shown above. Further deepening of the thermokarst depression is probably restricted by the lower boundary of ice complex deposits and the underlying ice-depleted sandy sequence at $20 \mathrm{~m}$ a.s.1. [Schirrmeister et al., 2003; Wetterich et al., 2008], an elevation level which has already been reached by the largest lake. Large and deep thermokarst depressions are also common in the northern Lena Delta in sandy deposits with lower ice contents [Grigoriev, 1993; Schwamborn et al., 2002; Ulrich et al., 2009]. Therefore, further thermokarst subsidence cannot be excluded. After the primary lake was drained, two secondary lakes (Lake 1 and Lake 3) remained within the incidental thermokarst depression. Lake 1 migrated over the basin floor in several stages in a north northwest direction, deepening into the basin floor and undercutting the slope as indicated by dif- ferent terrace levels within the depressions (Figure 4a). This process was strongly influenced by high insolation and higher temperatures on south southeast facing slopes. Lake 2 drained into the thermokarst depression later from an adjacent small depression. Currently, this lake is migrating to the north northeast. The steepest slope angles and disturbed vegetation cover caused by the highest insolation values and comparatively higher temperatures (Figures 9 and 11) on the slope north of the lake confirm ongoing lateral thermokarst development (Figure 18). As the soil thermal energy balance is disturbed, slope instability, steepness, and therefore lateral thermokarst development are forced by solar insolation.

\subsection{Implications for Scalloped Depression Development on Mars}

[40] On Earth, steeper south facing thermokarst depression slopes are geomorphologically more active. This activity is forced directly by solar insolation and therefore higher temperatures in the investigated thermokarst depression on the ice complex remnants of Kurungnakh Island. Less erosional activity of north facing slopes is indicated by areal flattening due to solifluction and cryo-
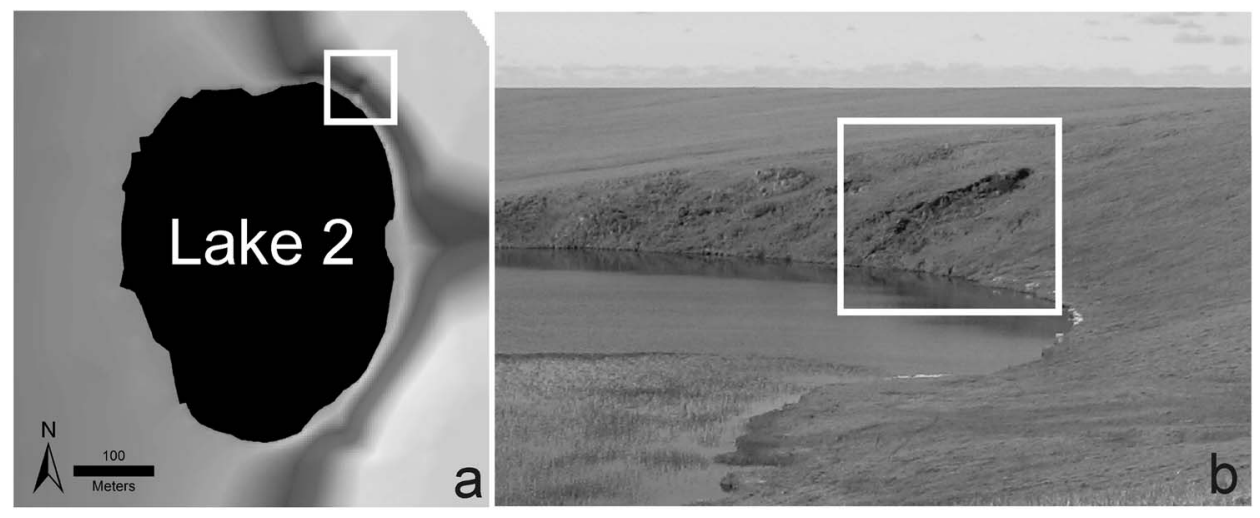

Figure 18. Slope movement and instability indicated by an area of disturbed vegetation on the steep south facing thermokarst depression slope north of Lake 2 (white rectangle). (a) Subset of the DEM (see Figure 4a). (b) Photograph of the lake and the described area. View to the north northwest. 
turbation processes in the terrestrial permafrost region [e.g., Williams and Smith, 1989; French, 2007]. By direct analogy, this implies that lateral scallop development on Mars is primarily forced on the steep pole-facing scarps in an equator-ward direction. This would have happened primarily during periods of high obliquity $\left(35^{\circ}-45^{\circ}\right.$ and more) (Figure 17).

[41] The relationship of obliquity changes to increasing erosion on midlatitude pole-facing crater slopes due to gully formation has already been suggested by various authors, predominantly for the Martian Southern Hemisphere [e.g., Costard et al., 2002; Dickson et al., 2007; Head et al., 2008; Morgan et al., 2010]. In the Northern Hemisphere, there is a shift of gully orientation at $40^{\circ} \mathrm{N}$ from pole-facing slopes to equator-facing slopes, suggesting that obliquity-driven insolation is not the only factor controlling gully formation [Kneissl et al., 2009]. However, a genetic linkage between obliquity-driven volatile-rich mantle formation on polefacing slopes and gully erosion in the Northern Hemisphere is proposed by, e.g., Bridges and Lackner [2006]. The morphometrical characteristics of the equator-facing scalloped depression slopes in UP (convex curvature, slightly inclined, flat) imply the absence of strong erosional processes as suggested by Lefort et al. [2009], but instead suggest areal flattening and likely current surface stabilization (Figure 13).

[42] Slow-to-absent morphological processes in the current stage of scalloped depression formation are also suggested by the thermal properties and albedo data, which always show lower temperatures and higher albedo of the scalloped terrain compared to the adjacent uplands within the investigated area (Figure 16). Nevertheless, our results support the general insolation model suggested by Morgenstern et al. [2007] and Lefort et al. [2009], which suggests the formation of scalloped depressions by insolation-driven ground ice sublimation.

[43] Different interpretations of scalloped depressions as residues of thermokarst lakes or alas depressions [e.g., Costard and Kargel, 1995; Soare et al., 2007, 2008] are not consistent with the definition of alas development on Earth [e.g., Everdingen, 2005] despite visual similarities. Evidence for thermokarst lake or alas formation due to ponding water cannot be identified in scalloped depressions on Mars [e.g., Lefort et al., 2009; Zanetti et al., 2010]. The ridges within the depressions were interpreted by Soare et al. [2007, 2008] as stages of alas growth; "the shallowest step represents the most recently formed part of the alas, whereas the deepest step indicates an older presence" [Soare et al., 2007]. If a lake is migrating on a thermokarst depression bottom and deepens due to thawing of ground ice and combined subsidence, then the highest lake terrace represents the oldest stage and the lowest the youngest. The ridges within the scallops which are trending subparallel to the proposed scarp retreat must have an opposite form if a lake is migrating and eroding the scarp as was described above for the terrestrial thermokarst depression (see also Figure 4). Furthermore, terrestrial thermokarst depressions and thermokarst lakes are usually connected by channels and narrow valleys (see also Figure 2). The drainage of thermokarst lakes, which results in the formation of thermokarst depressions (i.e., alasses), occurs via thermoerosional valleys [e.g., Hill and Solomon, 1999; Grosse et al., 2007]. Such features implying the former existences of flowing water between or the drainage of standing water bodies do not exists in Martian scalloped terrain (Figure 14). The landscape geomorphology in UP points to a dry origin of the scalloped depressions. The coalescence to scalloped terrain took place by areal expansion and multiphase lowering without channel incision. Warner et al. [2010] show evidence for wet thermokarst, i.e., thermokarst-like depressions connected by narrow channels. However, these features are much older and are therefore not further discussed here. In contrast, wet thermokarst degradation analogous to terrestrial retrogressive thaw slumps and thaw lakes is proposed by Balme and Gallagher [2009] for a study site in Athabasca Vallis near the Martian equator. The region is characterized by shallow basins, which are linked by fluvial-like channels. Retrogressive erosional scarps occur along the margins of the basins. With many of these scarps dendritic channels are associated. Balme and Gallagher [2009] suggest an origin during warmer conditions in the recent past including the thawing of ground ice by standing water bodies followed by surface subsidence and the lateral erosion by thaw slumps.

[44] With respect to former studies [Morgenstern et al., 2007; Lefort et al., 2009; Zanetti et al., 2010], the formation theory of scalloped depressions is modified here in particular for the volatile (ice)-rich UP deposits (Stage 0 in Figure 19). Scallop formation started at weak points like large thermal contraction cracks [Zanetti et al., 2010] or the small-relief surface depressions proposed by Lefort et al. [2009]. During low to moderate Martian obliquity a small depression, symmetric in cross section, was formed by homogeneous ground ice sublimation and subsequent subsidence of the ice-depleted surface material (Stage 1 in Figure 19). If temperatures were very low and ice thawing was unlikely [e.g., Costard et al., 2002; Hecht, 2002], the comparatively slow process of ground ice sublimation would have led to a consistent and homogeneous subsidence. Within the investigated area, small isolated depressions (around $100 \mathrm{~m}$ in diameter) that are not asymmetric but rather bowl-shaped represent an initial scallop stage. At this time, during which the orbital configuration was comparable to that of the present day, insolation and temperatures were permanently higher on the equator-facing depression slopes than on the pole-facing slopes (Figure 17a). The continuous ice sublimation led to an areal flattening of the equator-facing slopes and further deepening of preexisting depressions, while the pole-facing slopes steepened because they were permanently shaded and stabilized by ice cementation (Stage 2 in Figure 19). When Mars' obliquity was changed to higher values and insolation increased (Figure 17b), scallop development moved in an equatorward lateral direction (Stage 3 in Figure 19). Increasing insolation on the pole-facing slopes would have forced slope instability and erosion by enhanced ground ice sublimation or even thawing. This suggestion has already been proposed as a possible stage of scalloped depression development by Lefort et al. [2009]. When the ice was lost as the major cementing material, the upper material layer of the pole-facing slope was interrupted (further destabilized) in weak areas such as in the cracks of the large polygons on the adjacent uplands, and slumped into the depression (Stage 3 in Figure 19). In this process the sediment mass slid on the still-frozen material beneath. Simultaneously, the 

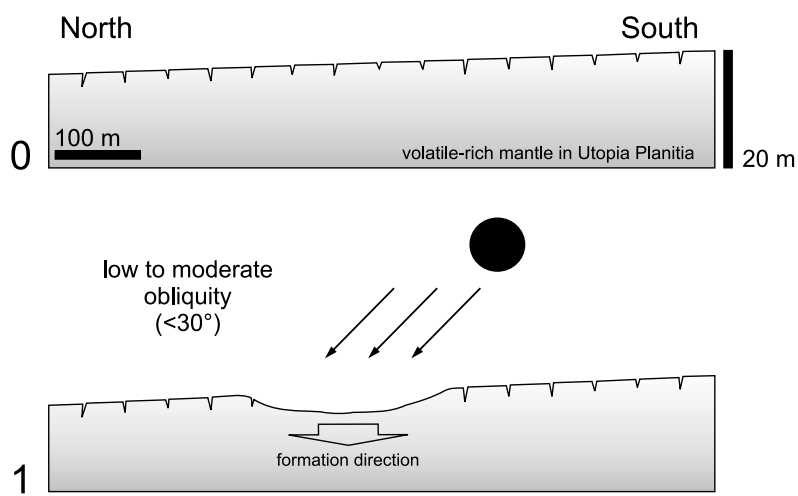

Subsidence

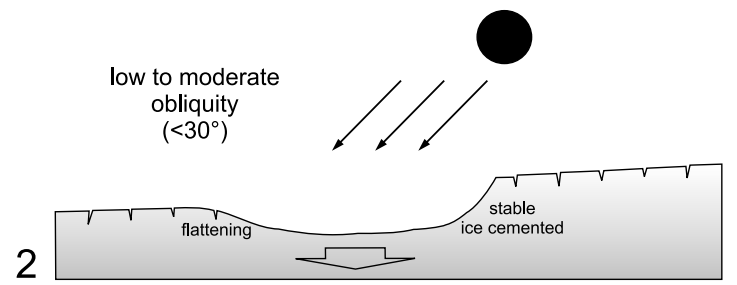

Subsidence
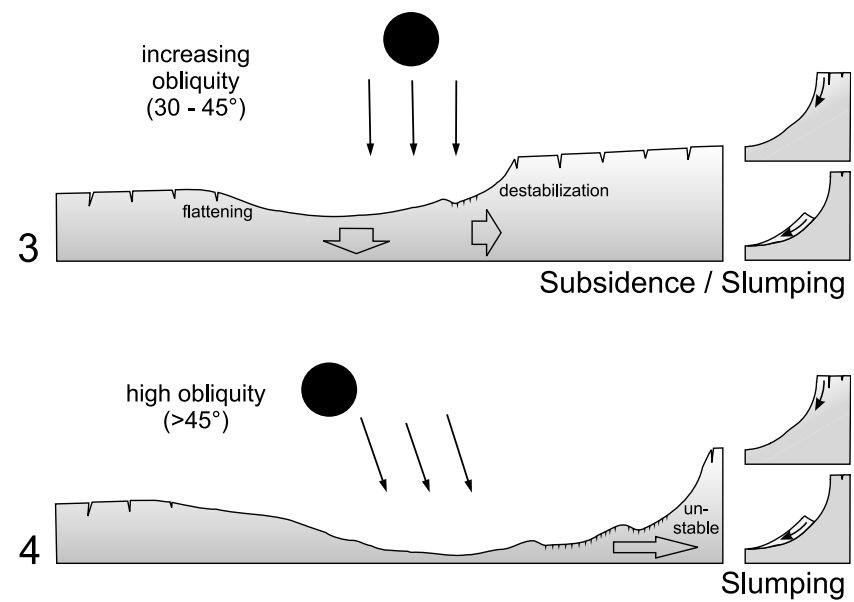

Figure 19. Schematic model for scalloped depression formation in Utopia Planitia including changes of Mars'orbital parameters. Stage 0: Surface of volatile (ice)-rich mantling deposits [Kreslavsky and Head, 2000; Mustard et al., 2001]. Stage 1: Homogenous ground ice sublimation resulted in an initial scallop stage. Stage 2: An asymmetrical depression was built by areal flattening of the equator (south) facing slope and due to ice cementation of the steepened pole (north) facing slope. Stage 3: Initiation of scalloped depression retrogressive growth in equator-ward direction by destabilization of the pole-facing slope due to obliquitydriven temperature increase. Stage 4: Maximization of equator-ward lateral scalloped depression formation during high obliquity periods.

sediment mass block-rotated around a horizontal axis in such a way as to tilt the former surface backward. Furthermore, this process led to a concave scarp profile and subparallel ridges with steeper sides facing the scarp, and the lateral movement and growth of the scallops in an equatorward direction (Stage 4 in Figure 19).
[45] Modeling results show that this process must have been maximized by ground ice thawing when Mars obliquity reached $>45^{\circ}$ (Figures $17 \mathrm{c}$ and 19). Maximum temperature events especially occurred if orbital eccentricity was high and/or the Martian northern summer coincided with perihelion (see above). The equator-facing slope was probably stabilized at a specific stage if the ice-depleted material formed an insulating layer which prevented further sublimation. However, the slumping processes were likely fast, brief events of increasing sublimation or even thawing on pole-facing scarps because these slopes were not flattened like the opposite slopes. The scarp was stabilized again because ice cement still existed inside after the uppermost material layer had slumped. The retrogressive growth stopped when Mars' obliquity tilted back to low degrees. The material was stabilized at the basin floor; strong thermal contraction cracking occurred at lower temperatures, while primary cracking developed perpendicular to the weak areas formed by the scarp front (Figure 15) as is known from similar processes in terrestrial permafrost regions [e.g., Lachenbruch, 1962, 1966; Yershov, 2004]. Such events happen periodically, as evidenced by increasing numbers of ridges with increasing scalloped depression sizes (Figure 13). The notion that each ridge may represent a single period of high obliquity [Lefort et al., 2009] is difficult to confirm, since such strong and comparatively fast slumping processes should happen more often during times of high obliquity and the favorable orbital configurations are rare [Laskar et al., 2004].

[46] The depths of scalloped depressions originated primarily by subsidence and suggest high-ground ice contents of the volatile (ice)-rich mantle material, although this material could be partly removed by eolian processes [e.g., Lefort et al., 2009, 2010; Zanetti et al., 2010]. However, the asymmetrical shape of the scallops in UP does not correspond to the prevailing wind direction in summer (from $\mathrm{S}$ to SSW) [Morgenstern et al., 2007], when scallop formation activity is likely to be most intense. Additionally, eolian dunes and dust devil tracks suggesting eolian erosion were not observed in the investigated area. The volume and the dimensions of the scalloped depression must be related to ground ice contents, which were presumably higher than the amounts proposed in the literature [e.g., Boynton et al., 2002; Feldman et al., 2004].

[47] Age determinations of the scalloped depression development are difficult to make. The occurrence of suitable orbital configurations in the last $10 \mathrm{Ma}$ suggests that the largest single scalloped depression and the coalesced part of the scalloped terrain could have formed within this time period, but younger stages of higher obliquity as well the additional coincidence with favorable orbital configurations (high eccentricity and/or summer coinciding with perihelion) suggest scallop formation at least in the last $5 \mathrm{Ma}$ as well. The model results propose that, at the most recent stages of high obliquity around 5.641 and $9.112 \mathrm{Ma}$, ground ice thawing may have forced scallop development and scallops could have developed in a few hundred thousand years. However, because the slumping process at the pole-facing slope must be a fast and abrupt event, the subsidence of the depression surfaces by sublimation must occur at a very slow rate [Lefort et al., 2009]. Furthermore, we think that scalloped depression formations probably remain dormant, 
preserved by the atmospheric conditions at low obliquity periods like the present, because the scalloped depressions appear unweathered and young.

\section{Conclusions}

[48] Thermokarst formation on Earth is strongly influenced and driven by standing water bodies. Direct comparison to Martian scalloped depressions is therefore problematic. However, studies of analogous thermokarst depressions in ice complex deposits in the Siberian Arctic, and investigations of the influence of solar insolation on terrestrial thermokarst morphology have improved our understanding of insolation-driven scallop development on Mars. The asymmetry of terrestrial thermokarst depression slopes with steeper slopes facing south (i.e., the equator) is confirmed by geomorphometric analyses. Both the results of insolation modeling and thermal Landsat satellite data imply a strong influence of incoming radiation on slope morphology. We propose a lateral development of thermokarst depressions and lake migration in a northern direction in the ice complex remnants in the Lena Delta.

[49] For the development of Martian asymmetric scalloped depressions, retrogressive growth in an equator-ward direction is postulated. The schematic model of the formation of scalloped depressions in UP shows a climatically controlled evolution. Our insolation modeling of scalloped depressions in UP supports the hypothesis that fast and abrupt slumping processes at the steep pole-facing scarps have occurred during periods of increasing obliquity within the last $10 \mathrm{Ma}$. The lateral scallop formation was maximized by possible ground ice thawing during periods of high obliquity, and when certain orbital configurations coincided. The equator-facing slopes were flattened by continuous, though slow, ground ice sublimation and depression surface subsidence. When Mars' orbit tilted back to low degrees of obliquity sublimation of ground ice was minimized and lateral scalloped depression formation stopped. The material was stabilized at the basin floor and strong thermal contraction cracking occurred.

[50] Acknowledgments. This research has been partly supported by the Helmholtz Association through the "Planetary Evolution and Life" research alliance. Field work was carried out within the framework of the Russian-German Lena 2008 expedition. We express our grateful appreciation to all colleagues involved in logistical and scientific support. The continuing efforts and support of the HiRISE and CTX teams in making their data publicly available and the ALOS project and ESA for providing ALOS data within the framework of the "LEDAM" project (awarded by ESA ADEN, PI Lantuit, ID 3616) are gratefully acknowledged. We thank Randolph L. Kirk (USGS, Flagstaff, USA) and colleagues for kindly providing a HiRISE DEM for our Martian study site. The paper benefited by English proofreading and valuable comments from Candace S. O'Connor (UAF, Fairbanks, Alaska) as well as by highly constructive suggestions from an anonymous reviewer.

\section{References}

Anisimov, O., and S. Reneva (2006), Permafrost and changing climate: The Russian perpective, Ambio, 35(4), 169-176.

Balme, M. R., and C. Gallagher (2009), An equatorial periglacial landscape on Mars, Earth Planet. Sci. Lett., 285(1-2), 1-15, doi:10.1016/j. eps1.2009.05.031.
Bauch, K. E., H. Hiesinger, and J. Helbert (2009), Estimation of Lunar surface temperatures: A numerical model, Lunar Planet. Sci., XXXX, Abstract 1789.

Berger, A., and M. F. Loutre (1991), Insolation values for the climate of the last 10 million years, Quat. Sci. Rev., 10, 297-317.

Boike, J., C. Wille, and A. Abnizova (2008), Climatology and summer energy and water balance of polygonal tundra in the Lena River Delta, Siberia, J. Geophys. Res., 113, G03025, doi:10.1029/2007JG000540.

Boynton, W. V., et al. (2002), Distribution of hydrogen in the near surface of Mars: Evidence for subsurface ice deposits, Science, 297(5578), 81-85, doi:10.1126/science.1073722.

Boytsov, M. N. (1965), Morphological evolution of thaw lake basins, in Anthropogenic period in the Arctic and Subarctic, vol. 143, edited by NIEDRA, pp. 327-340, Research Institute Geology of the Arctic, Moscow, Russia.

Bridges, N. T., and C.N. Lackner (2006), Northern hemisphere Martian gullies and mantled terrain: Implications for near-surface water migration in Mars' recent past, J. Geophys. Res., 111, E09014, doi:10.1029/ 2006JE002702.

Brown, J., O. J. Ferrians Jr., J. A. Heginbottom, and E. S. Melnikov (1998), Circum-Arctic map of permafrost and ground ice conditions, Natl. Snow and Ice Data Cent., Boulder, $\mathrm{CO}$.

Burr, D.M., K. L. Tanaka, and K. Yoshikawa (2009), Pingos on Earth and Mars, Planet. Space Sci., 57(5-6), 541-555, doi:10.1016/j.pss.2008. 11.003 .

Carr, M. H., and J. W. Head (2009), Geologic history of Mars, Earth Planet. Sci. Lett., 294(3-4), 185-203, doi:10.1016/j.epsl.2009.06.042.

Carson, C. E. (2001), The oriented thaw lakes: A retrospective, in Fifty More Years Below Zero, Tributes and Meditations for the Naval Arctic Research Laboratory's First Half Century at Barrow, Alaska, edited by D. W. Norton, pp. 129-137, Arctic Institute of North America, Calgary, AB, Canada.

Chander, G., B. L. Markham, and D.L. Helder (2009), Summary of current radiometric calibration coefficients for Landsat MSS, TM, ETM+, and EO-1 ALI sensors, Remote Sens. Environ., 113, 893-903, doi:10.1016/ j.rse.2009.01.007

Christensen, P. R., et al. (2004), The Thermal Emission Imaging System (THEMIS) for the Mars 2001 odyssey mission, Space Sci. Rev., 110, $85-130$.

Costard, F., F. Forget, N. Mangold, and J. P. Peulvast (2002), Formation of recent Martian debris flows by melting of near-surface ground ice at high obliquity, Science, 295(5552), 110-113, doi:10.1126/science.1066698.

Costard, F. M., and J. S. Kargel (1995), Outwash plains and thermokarst on Mars, Icarus, 114, 93-112, doi:10.1006/icar.1995.1046.

Côté, M. M., and C. R. Burn (2002), The oriented lakes of Tuktoyaktuk Peninsula, Western Arctic Coast, Canada - a GIS-based analysis, Permafrost Periglac., 13, 61-70.

Crampton, C. B. (1977), A note on asymmetric valleys in the central Mackenzie River catchment, Canada, Earth Surf. Processes, 2, 427-429.

Czudek, T., and J. Demek (1970), Thermokarst in Siberia and its influence on the development of lowland relief, Quat. Res., 1, 103-120.

de Pablo, M. A., and G. Komatsu (2009), Possible pingo fields in the Utopia basin, Mars: Geological and climatical implications, Icarus, 199(1), 49-74, doi:10.1016/j.icarus.2008.09.007.

Dickson, J. L., J. W. Head, and M. Kreslavsky (2007), Martian gullies in the southern mid-latitudes of Mars: Evidence for climate-controlled formation of young fluvial features based upon local and global topography, Icarus, 188, 315-323, doi:10.1016/j.icarus.2006.11.020.

Everdingen, R. O. V. (ed.) (2005), Multi-Language Glossary of Permafrost and Related Ground-Ice Terms, International Permafrost Association, Univ. of Calgary, Calgary, Canada (Available at http://nsidc.org/fgdc/ glossary).

Feldman, W. C., et al. (2004), Global distribution of near-surface hydrogen on Mars, J. Geophys. Res., 109, E09006, doi:10.1029/2003JE002160.

French, H. M. (1970), Soil temperatures in the active layer, Beaufort plain, Arctic, 23(4), 229-239.

French, H. M. (2007), The Periglacial Environment, 3rd ed., 458 pp., John Wiley, Chichester, U. K.

Frouin, R., C. Gautier, K. B. Katsaros, and R. J. Lind (1988), A comparison of satellite and empirical formula techniques for estimating insolation over the oceans, J. Meteorol., 27, 1016-1023.

Fu, P., and P. M. Rich (1999), Design and implementation of the Solar Analyst: An ArcView extension for modeling solar radiation at landscape scales, in Proceedings of the Nineteenth Annual ESRI User Conference, San Diego, USA. (Available at http://proceedings.esri.com/library/ userconf/proc99/proceed/papers/pap867/p867.htm).

Grigoriev, M. N. (1993), Cryomorphogenesis in the Lena Delta, 176 pp., Permafrost Institute Press, Yakutsk. 
Grom, J. D., and W. H. Pollard (2008), A study of high arctic retrogressive thaw slump dynamics, Eureka Sound Lowlands, Ellesmere Island, in Permafrost: Proceedings of the 9th International Conference on Permafrost 2008, edited by D. L. Kane and K. M. Hinkel, pp. 545-550, Institute of Northern Engineering, Univ. of Alaska Fairbanks.

Grosse, G., L. Schirrmeister, and T. J. Malthus (2006), Application of Landsat-7 satellite data and a DEM for the quantification of thermokarst-effected terrain types in the periglacial Lena-Anabar coastal lowland, Pol. Res., 25, 51-67.

Grosse, G., L. Schirrmeister, C. Siegert, V. V. Kunitsky, E. A. Slagoda, A. A. Andreev, and A. Y. Dereviagyn (2007), Geological and geomorphological evolution of a sedimentary periglacial landscape in Northeas Siberia during the Late Quaternary, Geomorphology, 86(1-2), 25-51.

Günther, F. (2009), Untersuchung der Thermokarstentwicklung im südlichen Lena Delta anhand multitemporaler Fernerkundungs- und Felddaten, diploma thesis, 96 pp., Tech. Univ. of Dresden, Dresden, Germany.

Head, J. W., J. F. Mustard, M. A. Kreslavsky, R. E. Milliken, and D. R. Marchant (2003), Recent ice ages on Mars, Nature, 426, 797-802.

Head, J. W., D. R. Marchant, and M. A. Kreslavsky (2008), Formation of gullies on Mars: Link to recent climate history and insolation microenvironments implicate surface water flow origin, $P N A S, 105(36)$, $13,258-13,263$

Hecht, M. (2002), Metastability of liquid water on Mars, Icarus, 156 , 373-386, doi:10.1006/icar.2001.6794.

Hill, P. R., and S. Solomon (1999), Geomorphologic and sedimentary evolution of a transgressive thermokarst coast, Mackenzie Delta Region, Canadian Beaufort Sea, J. Coastal Res., 15, 1011-1029.

Hinkel, K. M., R. C. Frohn, F. E. Nelson, W. R. Eisner, and R. A. Beck (2005), Morphometric and spatial analysis of thaw lakes and drained thaw lake basins in the western arctic coastal plain, Alaska, Permafrost Periglac., 16, 327-341.

Hutchinson, M. F. (1989), A new procedure for gridding elevation and stream line data with automatic removal of spurious pits, J. Hydrol., $106,211-232$.

Kieffer, H. H., T. N. Titus, K. F. Mullins, and P. R. Christensen (2000) Mars south polar spring and summer behavior observed by TES: Seasonal cap evolution controlled by frost grain size, J. Geophys. Res., 105(E4), 9653-9700, doi:10.1029/1999JE001136.

Kirk, R. L., et al. (2008), Ultrahigh resolution topographic mapping of Mars with MRO HiRISE stereo images: Meter-scale slopes of candidate Phoenix landing sites, J. Geophys. Res., 113, E00A24, doi:10.1029/ 2007JE003000.

Kneissl, T., D. Reiss, S. van Gasselt, and G. Neukum (2009), Distribution and orientation of northern-hemisphere gullies on Mars from the evaluation of HRSC and MOC-NA data, Earth Planet. Sci. Lett., doi:10.1016/ j.eps1.2009.05.018, in press.

Krbetschek, M. R., G. Gonser, and G. Schwamborn (2002), Luminescence dating results on sediment sequences of the Lena Delta, Polarforschung, $70,83-88$

Kreslavsky, M. A., and J. W. Head (2000), Kilometer-scale roughness of Mars: Results from MOLA data analysis, J. Geophys. Res., 105(E11), 26,695-26,711, doi:10.1029/2000JE001259.

Kreslavsky, M. A., and J. W. Head (2002), Mars: Nature and evolution of young latitude dependent water-ice-rich mantle, Geophys. Res. Lett. 29(15), 1719, doi:10.1029/2002GL015392.

Kumar, P. V. H., N. M. Kumar, and B. Mathew (1991), Insolation over the Arabian Sea during the southwest monsoon, Boundary Layer Meteorol. 56, 197-203.

Lachenbruch, A. H. (1962), Mechanics of thermal contraction cracks and ice-wedge polygons in permafrost, Spec. Pap. Geol. Soc. Am., 70, 68 pp

Lachenbruch, A. H. (1966), Contraction theory of ice-wedge polygons: A qualitative discussion, in Proceedings Permafrost International Conference, Lafayette, Indiana, November 1963, Publ. 1287, pp. 63-71, U.S. Natl. Acad. Sci., Washington, D. C.

Laevastu, T. (1960), Factors affecting the temperature of the surface layer of the sea, Comment. Phys. Math., 25, 1-136.

Laskar, J., A. C. M. Correia, M. Gastineau, F. Joutel, B. Levrard, and P. Robutel (2004), Long term evolution and chaotic diffusion of the insolation quantities of Mars, Icarus, 170, 343-364, doi:10.1016/j.icarus 2004.04.005.

Lefort, A., P. S. Russell, N. Thomas, A. S. McEwen, C. M. Dundas, and R. L. Kirk (2009), Observations of periglacial landforms in Utopia Planitia with the High Resolution Imaging Science Experiment (HiRISE), J. Geophys. Res., 114, E04005, doi:10.1029/2008JE003264.

Lefort, A., P. S. Russell, and N. Thomas (2010), Scalloped terrain in Peneus and Amphitrites Paterae region of Mars as observed by HiRISE, Icarus, 2005(1), 259-268, doi:10.1016/j.icarus.2009.06.005.

Levy, J., J. Head, and D. Marchant (2009), Thermal contraction crack polygons on Mars: Classification, distribution, and climate implications from HiRISE observations, J. Geophys. Res., 114, E01007, doi:10.1029/ 2008JE003273.

Lewkovicz, A. G. (1986), Headwall retreat of ground ice slumps, Bank Island, Northwest Territories, Can. J. Earth Sci., 24, 1077-1085.

Malin, M. C., et al. (2007), Context Camera investigation on board the Mars Reconnaissance Orbiter, J. Geophys. Res., 112, E05S04 doi:10.1029/2006JE002808

McEwen, A. S., et al. (2007), Mars Reconnaissance Orbiter's HighResolution Imaging Science Experiment (HiRISE), J. Geophys. Res. 112, E05S02, doi:10.1029/2005JE002605.

McGill, G. E. (1989), Buried topography of Utopia, Mars: Persistence of a giant impact depression, J. Geophys. Res., 94, 2753-2759, doi:10.1029/ JB094iB03p02753.

Mellon, M. T., B. M. Jakosky, H. H. Kieffer, and P. R. Christensen (2000), High-resolution thermal inertia mapping from the Mars Global Surveyor Thermal Emission Spectrometer, Icarus, 148, 437-455, doi:10.1006/ icar.2000.6503

Morgan, G., J. W. Head, F. Forget, J.-B. Madeleine, and A. Spiga (2010) Gully formation on Mars: Two recent phases of formation suggested by links between morphology, slope orientation and insolation history, Icarus, doi:10.1016/j.icarus.2010.02.019, in press.

Morgenstern, A., E. Hauber, D. Reiss, S. van Gasselt, G. Grosse, and L. Schirrmeister (2007), Deposition and degradation of a volatile-rich layer in Utopia Planitia and implications for climate history on Mars, J. Geophys. Res., 112, E06010, doi:10.1029/2006JE002869.

Morgenstern, A., M. Ulrich, F. Guenther, S. Roessler, and H. Lantuit (2008a), Combining ALOS data and field investigations for the reconstruction of thermokarst evolution in the North Siberian Lena Delta, in Proceedings of the "Second ALOS PI 2008 Symposium" (CD-ROM), ESA SP-664, ESA Communication Production Office, ESA, Noordwijk, Netherlands. (http://hdl.handle.net/10013/epic.31924)

Morgenstern, A., G. Grosse, and L. Schirrmeister (2008b), Genetic, morphological, and statistical characterization of lakes in the permafrostdominated Lena Delta, in Permafrost: Proceedings of the 9th International Conference on Permafrost 2008, edited by D. L. Kane and K. M. Hinkel, pp. 1239-1244, Institute of Northern Engineering, Univ. of Alaska, Fairbanks.

Mustard, J. F., C. D. Cooper, and M. K. Rifkin (2001), Evidence for recent climate change on Mars from the identification of youthful near-surface ground ice, Nature, 412, 411-414.

Overduin, P. P., and D. L. Kane (2006), Frost boils and soil ice content: Field observations, Permafrost Periglac., 17, 291-307.

Paige, D. A. (2002), Near-surface liquid water on Mars, Lunar Planet. Sci., XXXIII, Abstract 2049.

Putzig, N. E., M. T Mellon, K. A. Kretke, and R. E. Arvidson (2005), Global thermal inertia and surface properties of Mars from the MGS mapping mission, Icarus, 173, 325-341, doi:10.1016/j.icarus.2004. 08.017 .

Reed, R. K. (1977), On estimating insolation over the ocean, J. Phys. Oceanogr., 7, 482-485.

Rich, P. M., R. Dubayah, W. A. Hetrick, and S. C. Saving (1994), Using viewshed models to calculate intercepted solar radiation: Applications in ecology, Am. Soc. Photogramm. Rem. Sens. Tech. Pap., 524-529. (Available at http://libraries.maine.edu/Spatial/gisweb/spatdb/acsm/ ac94060.html)

Romanovskii, N. N., H. W. Hubberten, A. V. Gavrilov, V. E. Tumskoy, G. S. Tipenko, M. N. Grigoriev, and C. Siegert (2000), Thermokarst and land-ocean interactions, Laptev Sea Region, Russia, Permafrost Periglac., 11, 137-152.

ROSHYDROMET (2009), Weather Information for Tiksi, Russian Federal Service for Hydrometeorology and Environmental Monitoring, Moscow. (Available at http://www.worldweather.org/107/c01040.htm)

Schirrmeister, L., V. V. Kunitsky, G. Grosse, G. Schwamborn, A. A. Andreev, H. Meyer, T. Kuznetsova, A. Bobrov, and D. Oezen (2003), Late Quaternary history of the accumulation plain north of the Chekanovsky Ridge (Lena Delta, Russia): A multidisciplinary approach, Pol. Geogr., 27, 277-319.

Schirrmeister, L., V. V. Kunitsky, G. Grosse, T. V. Kuznetsova, A. Y. Derevyagin, S. Wetterich, and C. Siegert (2008), The Yedoma Suite of the northeastern Siberian shelf region - Characteristics and concept of formation, in Permafrost: Proceedings of the 9th International Conference on Permafrost 2008, edited by D. L. Kane and K. M. Hinkel, pp. 1595-1601, Institute of Northern Engineering, Univ. of Alaska Fairbanks.

Schwamborn, G., V. Rachold, and M. N. Grigoriev (2002), Late Quaternary sedimentation history of the Lena Delta, Quat. Int., 89, 119-134.

Sharp, R. P. (1973), Mars: Fretted and chaotic terrain, J. Geophys. Res., 78, 4073-4083, doi:10.1029/JB078i020p04073. 
Smith, D. E., et al. (2001), Mars Orbiter Laser Altimeter: Experiment summary after the first year of global mapping of Mars, J. Geophys. Res., 106(E10), 23,689-23,722, doi:10.1029/2000JE001364.

Soare, R. J., D. M. Burr, and J. M. Wan Bun Tseung (2005), Possible pingos and a periglacial landscape in northwest Utopia Planitia, Icarus, 174, 373-382, doi:10.1016/j.icarus.2004.11.013.

Soare, R. J., J. S. Kargel, G. R. Osinski, and F. Costard (2007), Thermokarst processes and the origin of crater-rim gullies in Utopia and western Elysium Planitia, Icarus, 191, 95-112, doi:10.1016/j.icarus.2007.04.018.

Soare, R. J., G. R. Osinski, and C. L. Roehm (2008), Thermokarst lakes and ponds on Mars in the very recent (late Amazonian) past, Earth Planet. Sci. Lett., 272, 382-393, doi:10.1016/j.epsl.2008.05.010.

Soloviev, P. A. (1962), Alas relief of Central Yakutia and its formation, in Permafrost and Accompanying phenomena in the territory of the Yakutian ASSR, pp. 38-53, Acad. Sci. USSR, Moscow.

Soloviev, P. A. (1973), Thermokarst phenomena and landforms due to frostheaving in Central Yakutia, Biuletyn Peryglacjalny, 23, 135-155.

Tanaka, K. L., J. A. Skinner, and T. M. Hare (2005), Geologic map of the northern plains of Mars, scale 1:15,000,000, U.S. Geol. Surv. Sci. Invest., Map 2888

Ulrich, M., G. Grosse, S. Chabrillat, and L. Schirrmeister (2009), Spectral characterization of periglacial surfaces and geomorphological units in the Arctic Lena Delta using field spectrometry and remote sensing, Remote Sens. Environ., 113, 1220-1235, doi:10.1016/j.rse.2009.02.009.

Warner, N., S. Gupta, J.-R. Kim, S.-Y. Lin, and J.-P. Muller (2010), Hesperian equatorial thermokarst lakes in Ares Vallis as evidence for transient warm conditions on Mars, Geology, 38, 71-74, doi:10.1130/ G30579.1.

Wetterich, S., S. Kuzmina, A. A. Andreev, F. Kienast, H. Meyer, L. Schirrmeister, T. Kuznetsova, and M. Sierralta (2008), Palaeoenvironmental dynamics inferred from late Quaternary permafrost deposits on Kurungnakh Island (Lena Delta, Northeast Siberia, Russia), Quat. Sci. Rev., 27, 1523-1540.

Williams, P. J., and M. W. Smith (Eds.) (1989), The Frozen Earth: Fundamentals of Geocryology, 306 pp., Cambridge Univ. Press., Cambridge.

Yershov, E. D. (2004), General Geocryology, Studies in Polar Research, 580 pp., Cambridge Univ. Press, New York.

Zanetti, M., H. Hiesinger, D. Reiss, E. Hauber, and G. Neukum (2010),

Distribution and evolution of scalloped terrain in the Southern Hemisphere, Mars, Icarus, 206(2), 691-706, doi:10.1016/j.icarus.2009. 09.010

K. E. Bauch and D. Reiss, Institut für Planetologie, Westfälische Wilhelms-Universität Münster, Münster, D-48149, Germany.

F. Günther, A. Morgenstern, M. Ulrich, and L. Schirrmeister, Alfred Wegener Institute for Polar and Marine Research, Research Unit Potsdam, Potsdam, D-14473 Germany.

E. Hauber, Institute for Planetary Research, German Aerospace Center (DLR), Berlin, D-12489, Germany.

S. Rössler, Limnological Institute, Technical University of Munich, Iffeldorf, D-85764, Germany. 